\title{
Public R\&D subsidies: collaborative versus individual place-based programs for SMEs
}

\author{
Andrea Bellucci • Luca Pennacchio • Alberto Zazzaro
}

Accepted: 7 February 2018 /Published online: 16 March 2018

(C) The Author(s) 2018

\begin{abstract}
This paper provides novel empirical evidence on the effectiveness of regional research and innovation policies for small and medium-sized enterprises (SMEs). It investigated two subsidy programs implemented at the regional level in central Italy. One program targeted SMEs' investments in individual research projects, and the other focused on collaborative research projects between SMEs and universities. Using a matched difference-in-differences approach, the empirical analysis showed that the two programs had different effects. The first was successful in stimulating additional private research and development $(\mathrm{R} \& \mathrm{D})$ investment and improving firms' performance. The second had weaker effects, mostly restricted to $R \& D$ expenditure and employment. These effects were not always uniformly distributed among project participants.
\end{abstract}

Keywords Public subsidies · R\&D - Impact evaluation · SMEs $\cdot$ Cooperation $\cdot$ Regional policy

JEL classification $\mathrm{H} 25 \cdot \mathrm{L} 52 \cdot \mathrm{O} 31 \cdot \mathrm{O} 38 \cdot \mathrm{R} 58$

\author{
A. Bellucci $(\bowtie)$ \\ European Commission Joint Research Centre, Unit B1 Finance \\ and Economy, Via E. Fermi 2749, 21027 Ispra, Varese, Italy \\ e-mail: andrea.bellucci@ec.europa.eu \\ L. Pennacchio \\ Parthenope University of Naples, Naples, Italy
}

\section{A. Zazzaro}

University of Naples Federico II, CSEF and MoFiR, Naples, Italy

\section{Introduction}

Research and innovation are key drivers of competitiveness, productivity, and economic growth for advanced economies. However, the limited appropriability of research results and information imperfections in capital markets means that private investments in innovation and research and development (R\&D) tend to be lower than is socially desirable. This, in turn, means that public policies in support of $R \& D$ are required to promote innovation investment in firms (Arrow 1962; Hall and Lerner 2010). Worldwide policy initiatives, such as OECD and EU innovation strategies, have placed research and innovation at the top of their agendas. They have put special emphasis on the importance of designing appropriate instruments to foster innovation in firms, and the key role of place-based innovation policies and collaborative research programs (OECD 2010).

The aim of this paper is to assess the effectivenessin terms of additionality - of place-based subsidy policies for R\&D investments by small and medium enterprises (SMEs). It considers two different programs supporting, respectively, individual and collaborative research projects. The subsidy programs were launched and run by a regional government in central Italy (the Marche region) during the period 2005-2008. ${ }^{1}$ They had very similar objectives, research activities, targeted firms, and eligible expenditure, which makes the assumption of ceteris paribus about the socio-economic

\footnotetext{
$\overline{1}$ The region and the programs are described in more detail in Appen-
} dix 1. 
environment very plausible. The only major difference was that the first type of subsidy program (hereafter, Program A) required SMEs to apply for grants individually by submitting their own research projects, and the second type of program (hereafter, Program B) only allowed firms to submit collaborative research projects, involving partnerships with local universities, research centers, and other firms. The programs were implemented in a limited time period and in the same institutional context, as well as having a similar design, so are highly comparable. This gives our empirical analysis the characteristics of a quasi-experiment, allowing us to directly assess the effectiveness of different subsidy schemes and provide some insight into the optimal design of R\&D policy.

This paper contributes to the literature on the evaluation of public subsidies for SMEs' R\&D on two main grounds. First, the paper focuses on the importance of program design for the effectiveness of public policies for R\&D and so aims to shed new light on an underinvestigated area of research. The vast majority of impact evaluation studies have focused on single programs of public subsidy to R\&D (e.g., Czarnitzki and Delanote 2015), and very little evidence exists on the differential impact of alternative subsidy schemes. Radas et al. (2015) compared direct subsidies with tax incentives granted to a sample of SMEs in Croatia and showed that the former were primary instruments for supporting R\&D in SMEs, and the latter had no additional effects on R\&D intensity in the firms receiving the subsidies. Bérubé and Mohnen (2009) studied a sample of Canadian firms and found that those benefiting from both R\&D subsidies and tax credits introduced more innovations than firms receiving only tax credits. Busom et al. (2014) found that R\&D subsidies tended to benefit financially constrained enterprises, and access to $R \& D$ tax credits was negatively associated with the probability that firms experienced financing constraints. More closely related to our paper, Engel et al. (2016) analyzed whether the effects of direct subsidies on firms' R\&D expenditure were influenced by the different forms of R\&D collaborations forced by the funding scheme. They considered a sample of R\&D-active German firms surveyed by the Federal Government and found that public funding was more effective in fostering $R \& D$ expenditure in firms involved in inter-firm cooperation than those involved in cooperation with research centers. Unlike Engel et al. (2016), we drew data from two regional subsidy programs and compared the additionality of individual and collaborative $R \& D$ projects. We also considered the impact on a wider range of outcomes around both input and output additionality.

Second, we considered place-based public programs. According to the concept of regional innovation system, many countries have adopted a regional development model that gives local governments a pivotal role in strengthening private R\&D. Regional governments are therefore earmarking large amounts of financial resources to support firms' R\&D activities, encouraging the formation of research networks and cooperation among the different parts of local innovation systems (Martin et al. 2011; Martin 2016). Despite this, there is still little empirical evidence on the effectiveness of place-based policies, and our paper helps to fill this gap.

Our impact evaluation analysis relied on a differencein-differences (DID) estimator combined with matching methods to select appropriate control groups. Overall, we found that both programs had some positive effects in supporting firms' $R \& D$, although there were some noticeable differences between the two programs. In particular, for individual subsidies, the empirical evidence clearly supports the input additionality hypothesis: R\&D expenditure, employment, and investments in tangible assets in recipient firms were significantly higher than in similar unsubsidized firms in the control group. The subsidies to individual research projects also showed output additionality effects and were successful in stimulating firms' patenting activity and profitability. Firms receiving public contributions from the collaborative subsidy program increased their $R \& D$ expenditure and employment, which were two major goals of the program. However, these firms also showed a decline in tangible and intangible investments compared to similar unsubsidized firms. The output additionality was also quite weak. The collaborative program appeared able to foster firms' profitability, but not sales and patent applications. Finally, the results suggest that the effectiveness of collaborative subsidies was not uniform among project participants.

The rest of the paper is structured as follows. Section 2 frames public intervention in the innovation literature and reviews selected papers on the effectiveness of public subsidies in promoting individual and collaborative R\&D in SMEs. This section also discusses the main costs and benefits associated with collaboration between firms and universities, which are particularly relevant for Program B. It also discusses the expected results of our impact evaluation analysis. 
Section 3 describes the dataset and the evaluation design, and Section 4 shows the main results and the sensitivity analysis. Section 5 provides concluding remarks and some policy implications.

\section{Related literature}

\subsection{Individual research and public subsidies}

Traditionally, the innovation literature has emphasized the important role of public intervention in fostering business innovation. Under the neoclassical theory of innovation, the main rationale behind the need for public policies to support private $\mathrm{R} \& \mathrm{D}$ and innovation is market failures. Firms cannot completely internalize the benefits of R\&D investments because knowledge has the characteristics of a public good (Arrow 1962; Stiglitz 1988). The presence of positive externalities means that the social return on R\&D spending is greater than the return gained by firms, so the level of private R\&D expenditure tends to be lower than the optimal social level. A negative effect is also associated with the imperfections of capital markets (Griliches 1986; Hall 2002). R\&D investments cannot be used as collateral and are characterized by high risk and uncertainty, so information asymmetries between borrowers and lenders may lead private firms to discard or defer socially valuable $R \& D$ projects. In these circumstances, a public intervention fostering private $R \& D$ efforts may have a positive impact on both subsidized firms and social welfare.

Different public instruments have been used to support R\&D in firms, including direct subsidies and tax incentives. A common characteristic of such instruments is that they are targeted towards individual firms. The empirical literature has extensively investigated the input and output additionality of public subsidies. The results are mixed and vary with the context (time period, country, industry), empirical approach, outcome variables, and level of government responsible for the policy program (David et al. 2000; Zuniga-Vicente et al. 2014). Studies have found that public subsidies have a positive impact on R\&D expenditure (Almus and Czarnitzki 2003; Hottenrott and Lopes-Bento 2014), firms' investments (Von Ehrlich and Seidel 2015), employment (Criscuolo et al. 2016), value added (Duch et al. 2009), innovation (Foreman-Peck 2013), and patent applications (Doh and Kim 2014). However, other studies have found that regional subsidies do not improve firms' productivity, R\&D investment, employment, labor productivity, or exports (Criscuolo et al. 2016; Karhunen and Huovari 2015; Martin et al. 2011). A common view is that public subsidies are more beneficial for smaller and younger firms than for larger, older ones (Busom et al. 2014; Gonzalez and Pazo 2008; Romero-Jordan et al. 2014), because of the severe "funding gap" which constrains their research and innovation activities (Alessandrini et al. 2010). Empirical literature has also shown that direct subsidies for SMEs are more effective than tax incentives in strengthening $R \& D$ orientation and innovation output, suggesting that these should be a primary instrument of innovation policy for local government (Radas et al. 2015).

In the last few decades, there has been an increasing use of regional subsidies to support individual firms' research in Italy. Cannone and Ughetto (2014) analyzed public subsidies in the Piedmont region in the period 2000-2006. They found that recipient firms increased their levels of tangible and intangible assets compared with non-funded firms in both short and medium terms. There was no evidence of a significant additional impact on recipients' output.

Bronzini and Iachini (2014) assessed the effectiveness of a regional subsidy program to local firms in the Emilia-Romagna region. Using a sharp regression discontinuity design, they found that small firms increased their investments by the amount of the subsidy, and large companies showed no significant increase in investment. In a follow-up to this study, Bronzini and Piselli (2016) analyzed the output additionality of the same subsidy program, documenting a significant impact on the number of patent applications, which was particularly strong for small firms. In the same region, Antonioli et al. (2014) considered survey-based data from a sample of manufacturing firms and found a positive effect on the recipient firms' ability to acquire and update new competencies, but not on the probability of establishing innovation cooperation.

Corsino et al. (2012) analyzed the effectiveness of a local R\&D policy in the province of Trento during 2002-2007. Using counterfactual models on a sample of manufacturing recipient firms, the evaluation analysis provided evidence of input, but not output, additionality. Regional subsidies for innovation stimulated intangible investments and investment in human capital, but had no effect on firms' turnover, productivity, or profitability. Finally, Bernini and Pellegrini (2011) and Cerqua 
and Pellegrini (2014) considered subsidies allocated to firms from southern Italian regions under a regional policy. Subsidized firms had higher growth rates of turnover, employment, and investments, but a weaker increase in total factor productivity than unsubsidized firms.

\subsection{Collaborative research and public subsidies}

The modern innovation literature has embraced the "system of innovation" perspective, which emphasizes that firms do not innovate in isolation but through continuous interactions with other organizations in the system at industry, regional, national, and supranational levels (Edquist 2005; Lundvall 1992). Innovation is considered to be a cumulative and non-linear process, reflecting formal and informal, voluntary and involuntary interactions between local firms, universities, research centers, and governments. The emphasis is on the creation and dissemination of knowledge, which is the real engine of R\&D and innovation (Bartelt et al. 2002; Etzkowitz and Leydesdorff 2000). The ability of a firm to innovate depends on in-house $R \& D$ investment, but the paradigm of open innovation has made clear that internal efforts alone may not be sufficient (Chesbrough 2003). Firms need to draw from, and collaborate with, a large number of actors from outside their organization to assimilate new knowledge and enhance their $R \& D$ and innovation (Guzzini and Iacobucci 2014; Laursen and Salter 2014).

The concept of regional innovation systems has emphasized that the creation and dissemination of knowledge is a localized process (Crescenzi et al. 2007; Moreno et al. 2005; Sonn and Storper 2008). Regional governments have an important role in coordinating and supporting the different actors involved in the knowledge-generating process - typically firms, universities, and other research institutes - by promoting the creation of local innovation networks (Cooke 1992; Etzkowitz and Leydesdorff 2000). This means that the decentralization of powers and resources from central to local governments is increasingly shaping the design of $\mathrm{R} \& \mathrm{D}$ policies in many countries.

In general, the literature on $\mathrm{R} \& \mathrm{D}$ cooperation indicates that alongside the benefits of fostering firms' innovativeness and internalizing positive spillover effects, there are significant drawbacks associated with research alliances. These include the costs of searching for partners, building up trust, and coordinating and monitoring the research network (Grimpe and Kaiser 2010; Hottenrott and Lopes-Bento 2016). Problems may also be associated with possible disclosure of private information, free-riding and opportunistic behaviors, lock-in situations and over-embeddedness (Gulati 1995; Lavie et al. 2010; Lokshin et al. 2011).

The system of innovation perspective suggests that several public instruments worldwide have supported the creation and development of local networks, across different configurations: science parks, research consortia, technology districts, and informal networks. All these public schemes encourage collaborations between firms or between firms and universities. The evaluation literature is, however, mixed on their effects. Some empirical analyses have supported the view that collaboration has a positive impact on firms' R\&D expenditure and patenting activity (Branstetter and Sakakibara 2002; Czarnitzki et al. 2007; Engel et al. 2016; Kang and Park 2012), as well as on employment (Falck et al. 2010). Other studies, however, have documented negative effects on venture creation (Audretsch et al. 2016) and private R\&D spending (Falck et al. 2010).

A number of papers have analyzed technological districts in Italy, innovation clusters created under a specific public policy to foster innovation and economic development at the regional level. Bertamino et al. (2016) compared the performance of firms participating in technological districts with similar firms outside these districts. The authors found a weak impact on the input and output of firms that joined the districts, mainly limited to small firms operating in some geographical areas of southern Italy. Ardovino and Pennacchio (2014) suggested that collaborative projects funded within technological districts stimulated the formation of partnerships between small and large firms, which may be particularly important for SMEs. Case studies conducted on some specific technological districts, however, recognized that research projects implemented within districts did not always lead to positive economic outcomes because of coordination problems among the actors involved, administrative burdens, and uncertain protection of intellectual property rights (Del Monte et al. 2016). Liberati et al. (2016) showed that firms in science and technology parks neither performed better nor innovated more than their counterparts elsewhere.

Program B in this paper forces firms to cooperate with other firms and with universities and research centers, financing only collaborative projects that involve three or more regional partners and at least one 
research institution. Collaborations between firms and research institutions tend to be privileged in industries with high technology intensity and rapid technological change, such as pharmaceutical and engineering fields (D'Este and Patel 2007; Giunta et al. 2016), where new breakthrough innovations can be realized (Klevorick et al. 1995). One of the crucial features of universityindustry relationships is the focus on basic, generic, and pre-competitive research. Inter-firm collaborations tend to be more oriented towards applied research and commercialization (Azagra-Caro et al. 2012; Bellucci and Pennacchio 2016). This in turn implies that research projects involving universities are more complex, riskier, longer-term, and more centered on the transfer of knowledge than other projects (Arora and Gambardella 1994; Hall et al. 2000).

Empirical analyses have emphasized that firms' innovation performance varies with different types of collaboration partners. University-industry cooperation, in particular, may improve firm performance, in terms of both the higher probability of applying for patents and achieving product innovations, and sales growth from the introduction of new products into the market (Arvanitis et al. 2008; Belderbos et al. 2004; Lööf and Broström 2008). Additionality effects of public funding have been found on R\&D expenditure, although with a lesser extent than those characterizing inter-firm cooperation (Czarnitzki et al. 2007; Engel et al. 2016), and on the proportion of employees working on R\&D (Scandura 2016).

The most relevant drawbacks for firms involved in research projects with universities probably derive from the coordination and management of the relationships. To assimilate the basic knowledge generated in these interactions, firms need to have both a strong R\&D capacity and a specialized staff. Under the concept of absorptive capacity (Cohen and Levinthal 1990), R\&D capability is the scientific and knowledge base, both in terms of R\&D investments and high-skilled workers, that enables firms to develop new products and processes and to absorb knowledge flows developed outside the organization (Laursen and Salter 2004). To enable the learning process, as well as to enhance trust, it is crucial that firms and universities build personal interactions through the creation of work teams (Fritsch and Lukas 2001; Sáez et al. 2002; Santoro and Chakrabarti 1999).

\subsection{Expected effects of the subsidy programs}

Overall, the theoretical and empirical literature on $R \& D$ suggests that public funding policies at the local level, if well-designed and implemented, play a key role in promoting additional private $R \& D$ investments and innovation outcomes. In this paper, we investigated both input and output additionality of public subsidies. The effects of public funding were estimated both during the implementation of the research projects, which we consider as short-term effects, and after the research projects had ended, which we consider as medium-term effects. These time horizons allowed us to evaluate whether the effects of public funding last over time or only show up during the funded projects.

The next section describes the outcome variables used in this impact evaluation analysis. This section focuses on the expected effectiveness of public subsidies to reinforce the broad categories of R\&D inputs and outputs of granted firms. We expect that input additionality effects, where present, will be bigger and more significant in the short term because they concern key resources needed to conduct research projects, such as $R \& D$ expenditure, $R \& D$ personnel, and investments in tangible/intangible assets. Output additionality should emerge at a later stage because it relates to the benefits of the funded projects on variables such as sales, profitability, and patent applications.

The literature does not provide any clear indication of the comparative benefits for individual and collaborative programs. $R \& D$ projects that involve collaboration between multiple partners can produce better or worse results than individual research projects, depending on whether synergy and spillover benefits exceed the coordination and free-riding costs. Cooperation can give firms access to the complementary resources of their partners, both tangible and intangibles, such as laboratories, machinery and equipment, and software. We can therefore expect that firms funded under Program B may dedicate fewer funds to investment in tangible and intangible assets than those funded under Program A. The former firms can also be expected to apply for more patents because research projects involving universities are oriented towards basic rather than applied research.

A primary feature of university-industry cooperation is that it is planned on a long-term basis and as a part of a long-term technological strategy of the firms involved (Mowery and Rosenberg 1989; Mytelka 1991). The additional input effects of research projects funded 
under Program B are therefore expected to be delayed, but possibly longer-lasting. The same may be true of output additionality, to the extent that collaborative projects suffer from a longer run-in phase.

\section{Data, variables, and evaluation design}

\subsection{Data sources}

The empirical analysis is based on an original and novel dataset combining different sources of information. Data related to regional programs are collected by the regional development agency for innovation (Marche Innovazione) together with the Department of Information Engineering (DIIGA) of the University Polytechnic of Marche in Ancona. Accounting data on subsidized and non-subsidized firms for the period 2003-2012 were drawn from AIDA, a database produced by Bureau van Dijk that collects balance sheet information on Italian companies. Lastly, we drew on patent data from REGPAT, the OECD database reporting information on patent applications to the European Patent Office (EPO) at the regional level.

The final dataset included 238 SMEs receiving public grants: 78 and 98 under the first and second rounds of Program A, and 62 under Program B. To investigate the causal effect of the regional subsidy programs on SMEs' R\&D input and output, we needed a control group of firms as similar as possible to those that had received local government grants (the treated group). Some studies have used control groups of firms that applied to public programs without receiving grants (e.g., Bronzini and Piselli 2016). Unfortunately, in this study, this was unfeasible because almost all applicant firms were funded under Program B. ${ }^{2}$ We therefore built our control groups from firms that did not apply to the subsidy programs under scrutiny. We extracted information from the AIDA database about all firms in the Marche region and excluded any that did not meet the eligibility criteria of the subsidy programs: (i) firms belonging to ineligible manufacturing sectors; (ii) firms in bankruptcy or in liquidation; (iii) large firms; and (iv) firms which benefit from other R\&D subsidies, either national or regional.

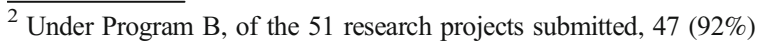
were approved by the committee of independent experts appointed by the regional government to evaluate the projects, and only four were rejected.
}

This resulted in a sample of 6067 SMEs, none of which had benefited from public funding for R\&D. A similar methodology has been used by several other studies dealing with evaluation of public programs (e.g., Cannone and Ughetto 2014; Michalek et al. 2016).

Table 1 shows descriptive statistics of our final sample, distinguishing between funded and non-funded SMEs. These figures were from 2004, the year before the start of Program A. On average, funded firms were older and larger than non-funded ones and applied for patents more frequently. Funded firms also had a stronger $R \& D$ intensity and lower indebtedness than nonfunded firms, although these differences were not statistically significant. The statistics on profitability were mixed: the ratio between earnings before interest, taxes, depreciation, and amortization (EBITDA) and sales was higher for subsidized firms, but non-subsidized ones had a higher return on equity. Finally, borrowing costs were significantly lower for subsidized firms, casting doubt on the relevance of financial motivation for applications for public subsidies in our sample. Firms funded under Program A were slightly larger and older than firms funded under Program B (see Table 2). The differences, however, were very small and the three groups of firms were substantially homogeneous, supporting the comparability of the two public programs.

\subsection{Outcome variables}

To assess the additional contribution of public subsidies to SMEs' R\&D, we considered both input and output variables. The main input indicator was firms' $R \& D$ spending ( $R \& D$ expenditure), the most widely used outcome in the literature on the effects of public policies on firms' R\&D (Zuniga-Vicente et al. 2014). The variable was computed as the ratio between R\&D expenditure and total sales. We also assessed the impact of subsidies on balance sheet variables associated with the expenditure eligible for public financing under the two programs: investments in tangible and intangible assets (Tangible investment and Intangible investment) and hiring of new R\&D personnel. Unfortunately, the AIDA database does not include direct information about these variables. We therefore used the annual percentage change in tangible and intangible assets, net of amortization, as proxies for tangible and intangible investments. Although this is only a rough measure of the investment actually realized by firms, both variables have been commonly used in the literature on the 
Table 1 Summary statistics of firms' characteristics and mean comparison between groups before the programs

\begin{tabular}{|c|c|c|c|c|c|c|c|c|}
\hline & \multicolumn{3}{|c|}{ Subsidized } & \multicolumn{3}{|c|}{ Non-subsidized } & \multicolumn{2}{|c|}{ Mean difference test } \\
\hline & Mean & Median & St. dev. & Mean & Median & St. dev. & $t$ statistic & $p$ value \\
\hline Age & 17.9 & 17 & 11.7 & 8.1 & 5 & 12.4 & 12.6 & 0.00 \\
\hline Sales* & 8338 & 5606 & 8844 & 3900 & 1935 & 6.069 & 7.6 & 0.00 \\
\hline Value added* & 2265 & 1609 & 2267 & 837 & 410.3 & 1468 & 50.4 & 0.00 \\
\hline Employees & 55.2 & 45 & 47.3 & 31.1 & 15 & 59.3 & 7.1 & 0.00 \\
\hline Total assets* & 7601 & 4780 & 7894 & 3636 & 1578 & 7662 & 7.5 & 0.00 \\
\hline EBITDA/sales & 11.6 & 7.6 & 39.6 & 9.3 & 7.3 & 9.1 & 2.9 & 0.00 \\
\hline ROE & 4.3 & 3.7 & 26.1 & 8.2 & 5.6 & 26.7 & -7.3 & 0.00 \\
\hline Tangible assets* & 1214 & 758 & 1324 & 1012 & 199.3 & 4898 & 0.8 & 0.40 \\
\hline Intangible assets* & 163.3 & 32.4 & 493.3 & 45.5 & 6.6 & 399.9 & 3.5 & 0.00 \\
\hline R\&D intensity (\%) & 0.5 & 0.04 & 1.0 & 0.3 & 0.02 & 4.1 & 1.6 & 0.10 \\
\hline Wages* & 1087 & 814.7 & 1020 & 679.6 & 186.3 & 896.5 & 6.4 & 0.00 \\
\hline Patents & 0.04 & 0.01 & 0.2 & 0.02 & 0.01 & 0.05 & 9.8 & 0.00 \\
\hline Borrowing cost (\%) & 4.9 & 4.4 & 3.5 & 5.8 & 5.0 & 4.5 & -2.1 & 0.03 \\
\hline Short-term borrowing & 0.8 & 0.9 & 0.1 & 0.8 & 0.9 & 0.1 & 1.4 & 0.16 \\
\hline Gearing ratio & 12.3 & 6.1 & 32.8 & 13.2 & 5.9 & 48.7 & -0.4 & 0.70 \\
\hline
\end{tabular}

*Thousands of euros

additionality of R\&D public policies (e.g., Bronzini and Iachini 2014). The AIDA database provides information on the total number of employees, without any distinction between R\&D personnel and other types of

Table 2 Balancing test for each program/round

\begin{tabular}{|c|c|c|c|c|c|c|}
\hline & \multicolumn{2}{|c|}{ Program A-2005 } & \multicolumn{2}{|c|}{ Program A-2007 } & \multicolumn{2}{|c|}{ Program B-2008 } \\
\hline & Subsidized & $\begin{array}{l}\text { Difference with } \\
\text { non-subsidized } \\
\text { after matching }\end{array}$ & Subsidized & $\begin{array}{l}\text { Difference with } \\
\text { non-subsidized } \\
\text { after matching }\end{array}$ & Subsidized & $\begin{array}{l}\text { Difference with } \\
\text { non-subsidized } \\
\text { after matching }\end{array}$ \\
\hline Age & 19.6 & -0.9 & 17.2 & 0.7 & 15.4 & 0.9 \\
\hline Sales $^{\mathrm{a}}$ & 10250 & 0.3 & 7882 & 0.4 & 7610 & 0.55 \\
\hline Total assets ${ }^{\mathrm{a}}$ & 9824 & 285 & 7323 & 654 & 7908 & 111.5 \\
\hline EBITDA/sales & 9.3 & 1.1 & 15.6 & -0.1 & 8.9 & -0.6 \\
\hline ROE & 3.8 & -1.5 & 4.5 & -1.3 & 4.5 & -1.0 \\
\hline Tangible assets ${ }^{\mathrm{a}}$ & 1369 & 49.1 & 1156 & 38.1 & 912.6 & 62.2 \\
\hline Intangible assets $^{\mathrm{a}}$ & 167.5 & 17.1 & 179.2 & 0.9 & 100.7 & 3.4 \\
\hline $\mathrm{R} \& \mathrm{D}$ intensity $(\%)$ & 0.7 & 0.001 & 0.3 & 0.001 & 1.0 & 0.001 \\
\hline Wages $^{\mathrm{a}}$ & 1369 & -33.2 & 1006 & 85.3 & 886.9 & 51 \\
\hline Patents & 0.06 & $0.02 *$ & 0.06 & 0.01 & 0.03 & 0.00 \\
\hline Borrowing cost (\%) & 4.9 & 0.1 & 4.7 & -0.1 & 5.3 & -0.2 \\
\hline $\begin{array}{l}\text { Short-term } \\
\text { borrowing }\end{array}$ & 0.8 & 0.05 & 0.8 & -0.03 & 0.9 & -0.02 \\
\hline
\end{tabular}

The table reports the mean values in the year before the programs

a Thousands of euros

*Statistically significant at the $10 \%$ level 
workers. We were therefore unable to test directly whether public funding encouraged subsidized firms to hire new researchers. However, as a proxy, we used the total amount of wages paid by firms (in thousands of euro), which should capture the employment of additional workers and the shift from low- to high-skilled and high-wage workers (Bronzini and Iachini 2014; Goolsbee 1998).

The analysis of input additionality is not sufficient to assess the effectiveness of public subsidies in fostering innovation. The rejection of the crowdingout hypothesis of private $R \& D$ investment does not mean that public funding actually leads to technological progress. Assessing the effects of public subsidies on innovation output is crucial for at least two reasons: first, because innovation is probably the ultimate goal of most programs supporting $R \& D$ activities and secondly, because public funding might affect innovation output, even if innovation input remains constant (Bronzini and Piselli 2016). We considered three outputs of innovation activity as outcome variables: $(i)$ the number of patent applications to the EPO, (ii) firms' sales, and (iii) firms' profitability (as return on equity). The number of patent applications is the most widely used indicator of innovation activity (Griliches 1990; Jaffe and Trajtenberg 2002) and has been used in previous studies on the effects of R\&D public policies (Bronzini and Piselli 2016; Costantini et al. 2015). However, the patenting activity of firms in our sample was quite low, because Italian firms generally tend not to apply for patents, and this may introduce high variability in our DID estimates. We therefore also considered the impact of subsidies on firms' total sales and profitability. These are very broad indicators of R\&D output, affected by many confounding factors other than firms' innovation strategies. However, a number of papers have used both variables in evaluating public policies on innovation (e.g., Lerner 1999).

A preliminary analysis of the descriptive statistics of outcome variables indicated the presence of some major outliers for the proxies for tangible and intangible investments. We therefore reduced the sample to between the first and ninety-ninth percentile of the distribution of the two variables. This procedure resulted in the loss of some observations, but only among untreated firms. The sample size of treated firms was unchanged. Other outcomes did not show any outliers.

\subsection{Empirical strategy}

The objective of the empirical analysis was to assess the causal effect of public subsidies on the outcome variables. Using the standard terminology of impact evaluation, the subsidy programs were the treatments, subsidized firms the treated units, firms not applying to public programs the untreated units, and the variables potentially affected by the programs the outcomes. We relied on a matched difference-in-differences (DID) approach to compare treated and non-treated units and to assess outcome changes before and after the receipt of subsidies. Using this technique, the firms receiving support and not applying for subsidies are often not random samples (Cowling 2016; Klette et al. 2000) and the direct comparison of the two groups can lead to strongly biased results. This was a real concern in our sample, where subsidized and non-subsidized firms showed several important differences (see Table 1). Such heterogeneity casts doubts on the random distribution of public grants across firms. To select appropriate control groups and mitigate the selection bias problem, we therefore combined DID with propensity score matching (PSM). PSM assumes that the distribution of public funding between treated and non-treated firms is based only on observable characteristics of firms. DID takes into account unobservable time-invariant factors, such as individual fixed characteristics and trend effects. Matched DID therefore allows observable and non-observable time-invariant variables to influence the outcome variables (Khandker et al. 2010).

The estimation procedure used two steps. First, we performed kernel PSM based on observed firm characteristics in the baseline year, or the year before the receipt of public subsidies: 2004 and 2006 for rounds 1 and 2 of Program A and 2007 for Program B. To ensure the overlapping of subsidized and nonsubsidized firms, we performed the PSM analysis with the option of common support. We used kernel PSM as matching algorithm, a non-parametric matching estimator that uses a weighted average of all non-funded firms on the common support region to identify matches for subsidized firms. The major advantage of this technique is that it uses all available information, while other algorithms use only a subset of untreated units to build the control group.

In the second step, we applied the DID method to estimate the average effect of the public programs. The years of matching varied by program/round and we 
aimed to identify the differential impact of Programs A and $\mathrm{B}$, so we replicated this procedure separately for each program. We also estimated separately the effects of the two rounds of Program A to assess the consistency of our findings on policy design and the additionality of individual versus collaborative research. Our estimation strategy consisted of a DID on repeated crosssectional data with a weighted least square regression, where observations were weighted by their propensity scores. Hirano et al. (2003) showed that this procedure yields a fully efficient estimator. Considering $t=0$ as the pre-treatment period, $t=2$ as the post-treatment period, $Y$ as the outcome variable, $T$ the treated firms receiving the subsidy, and $C$ the untreated firms in the control group, the mean difference in the outcome of the public programs can be written as

$$
\begin{aligned}
D D & =\frac{1}{N_{T_{2}}}\left[\sum_{i \in T_{2}} Y_{i 2}^{T}-\sum_{j \in C_{2}} \omega(i, j) Y_{j 2}^{C}\right] \\
& -\frac{1}{N_{T_{0}}}\left[\sum_{i \in T_{0}} Y_{i 0}^{T}-\sum_{j \in C_{0}} \omega(i, j) Y_{j 0}^{C}\right]
\end{aligned}
$$

where $i$ and $j$ indicate treated and untreated firms, $N$ is the total number of observations, and $\omega($.) is the weight of the kernel PSM.

We ran DID in different years after the treatment to capture short- and medium-term effects, because the literature shows that the full effect of a subsidy may be distributed over several years (Klette and Møen 2011). Identifying $t$ as the year of funding, we consider years $t$ and $t+1$ as short term and years $t+2, t+3$, and $t+4$ as the medium term. Considering, for example, Program B, the effects on outcome variables were assessed until 2012, the last year included in the dataset.

\section{Results}

This section provides the findings of the impact evaluation analysis, including the results of the matching procedure used to identify the control group of untreated firms, the DID estimates for the impact of the two public interventions, and the robustness checks to confirm the main results.

\subsection{Matching}

The counterfactual match for each subsidized firm was obtained through kernel PSM. Gaussian kernel was used with the common support option to improve the comparability between treated and untreated firms and the reliability of the procedure. The set of matching covariates included the following firm characteristics: size, proxied by total assets; age, calculated as the number of years since firm establishment; profitability, as return on assets (ROA) and earnings before interest, taxes, depreciation, and amortization (EBITDA) over sales; indebtedness, as short-term borrowing; borrowing costs; and sector of activity. To increase the comparability between treated and untreated firms, this set of covariates was augmented with the specific outcomes under scrutiny.

We emphasized the importance of the common support option in our sample. From PSM, five subsidized firms did not have similar counterparts in the control group, but fewer than $9 \%$ of non-funded firms did not have similar counterparts in the treated group, depending on the outcome variable considered. We therefore restricted the estimates to firms on common support, to ensure a good balancing of matching variables.

The quality of matching was assessed through a balancing test, which compared the firms funded under each round of Program A and under Program B to the untreated firms included in the control groups, before and after matching. After matching, the differences between the mean values of treated and control firms were very small and not statistically significant for the three groups, suggesting the validity of our matching procedure (Table 2). Only the variable measuring patents was higher for funded firms. The significance of this, however, was low (10\%) and the difference was not significant for the second round of Program A. All other variables in the three samples were well balanced.

\subsection{Main findings}

The results of the impact evaluation analysis are summarized in Table 3. For each program/round and for each outcome, the table shows the number of treated firms, the number of matched firms in the control group, and the average effect of the programs in the short and medium terms. The full set of estimates, year by year, is shown in Appendix 2, while this section focuses on the short- and medium-term average effects. 
Table 3 The effect of regional subsidies on SMEs' activity—summary of the impact evaluation results

\begin{tabular}{|c|c|c|c|}
\hline & $\begin{array}{l}\text { Program A-2005 } \\
\text { (baseline 2004) }\end{array}$ & $\begin{array}{l}\text { Program A-2007 } \\
\text { (baseline 2006) }\end{array}$ & $\begin{array}{l}\text { Program B } \\
\text { (baseline 2007) }\end{array}$ \\
\hline \multicolumn{4}{|l|}{ Panel A: input additionality } \\
\hline \multicolumn{4}{|l|}{ R\&D expenditure } \\
\hline Short-term average effect & $\begin{array}{l}0.002 \\
(0.001)\end{array}$ & $\begin{array}{l}0.002 * * \\
(0.001)\end{array}$ & $\begin{array}{l}0.003 * * * \\
(0.001)\end{array}$ \\
\hline Medium-term average effect & $\begin{array}{l}0.010 * * * \\
(0.002)\end{array}$ & $\begin{array}{l}0.005 * * * \\
(0.001)\end{array}$ & $\begin{array}{c}-0.001 \\
(0.001)\end{array}$ \\
\hline Number of treated/untreated firms & $51 / 1324$ & $51 / 1647$ & $36 / 1345$ \\
\hline \multicolumn{4}{|l|}{ Tangible investments } \\
\hline Short-term average effect & $\begin{array}{l}0.107 * * \\
(0.049)\end{array}$ & $\begin{array}{l}0.058 * \\
(0.048)\end{array}$ & $\begin{array}{l}-0.484 * * * \\
(0.059)\end{array}$ \\
\hline Medium-term average effect & $\begin{array}{l}0.020 \\
(0.041)\end{array}$ & $\begin{array}{l}0.004 \\
(0.029)\end{array}$ & $\begin{array}{c}-0.064 \\
(0.073)\end{array}$ \\
\hline Number of treated/untreated firms & $66 / 2639$ & $82 / 3829$ & $45 / 4108$ \\
\hline \multicolumn{4}{|l|}{ Intangible investments } \\
\hline Short-term average effect & $\begin{array}{l}0.258 \\
(0.170)\end{array}$ & $\begin{array}{c}-0.033 \\
(0.129)\end{array}$ & $\begin{array}{l}-0.519 * * * \\
(0.142)\end{array}$ \\
\hline Medium-term average effect & $\begin{array}{l}-0.114 \\
(0.146)\end{array}$ & $\begin{array}{c}-0.128 \\
(0.120)\end{array}$ & $\begin{array}{l}-0.631 * * * \\
(0.132)\end{array}$ \\
\hline Number of treated/untreated firms & $73 / 3489$ & $80 / 3349$ & $42 / 3702$ \\
\hline \multicolumn{4}{|l|}{ Wages } \\
\hline Short-term average effect & $\begin{array}{l}90.98 * \\
(50.42)\end{array}$ & $\begin{array}{l}71.53 * * \\
(36.44)\end{array}$ & $\begin{array}{l}79.68 * * * \\
(29.21)\end{array}$ \\
\hline Medium-term average effect & $\begin{array}{l}305.6^{* * * *} \\
(49.2)\end{array}$ & $\begin{array}{l}144.5^{* * * *} \\
(34.4)\end{array}$ & $\begin{array}{l}69.45 * * \\
(27.23)\end{array}$ \\
\hline Number of treated/untreated firms & $73 / 3489$ & $90 / 4431$ & $48 / 4459$ \\
\hline \multicolumn{4}{|l|}{ Panel B: output additionality } \\
\hline \multicolumn{4}{|l|}{ Sales } \\
\hline Short-term average effect & $\begin{array}{l}0.452 \\
(0.386)\end{array}$ & $\begin{array}{l}0.503 * \\
(0.297)\end{array}$ & $\begin{array}{c}-0.248 \\
(0.210)\end{array}$ \\
\hline Medium-term average effect & $\begin{array}{l}0.239 \\
(0.386)\end{array}$ & $\begin{array}{l}0.531 * \\
(0.293)\end{array}$ & $\begin{array}{c}-0.339 \\
(0.209)\end{array}$ \\
\hline Number of treated/untreated firms & $73 / 3645$ & $89 / 4244$ & $48 / 4542$ \\
\hline \multicolumn{4}{|l|}{ ROE } \\
\hline Short-term average effect & $\begin{array}{l}2.06 * * \\
(0.96)\end{array}$ & $\begin{array}{l}2.62 * * \\
(1.02)\end{array}$ & $\begin{array}{l}-3.02 * * * \\
(1.03)\end{array}$ \\
\hline Medium-term average effect & $\begin{array}{l}0.270 \\
(0.916)\end{array}$ & $\begin{array}{l}3.23 * * * \\
(0.96)\end{array}$ & $\begin{array}{l}6.07 * * * \\
(0.87)\end{array}$ \\
\hline Number of treated/untreated firms & $71 / 3420$ & $90 / 3974$ & $49 / 4596$ \\
\hline \multicolumn{4}{|l|}{ Patents } \\
\hline Short-term average effect & $\begin{array}{l}0.005 \\
(0.013)\end{array}$ & $\begin{array}{l}0.008 \\
(0.006)\end{array}$ & $\begin{array}{l}0.008 \\
(0.006)\end{array}$ \\
\hline Medium-term average effect & $\begin{array}{l}0.079 * * * \\
(0.012)\end{array}$ & $\begin{array}{l}0.012 * \\
(0.007)\end{array}$ & $\begin{array}{l}0.009 \\
(0.007)\end{array}$ \\
\hline Number of treated/untreated firms & $72 / 3639$ & $89 / 4279$ & $48 / 4624$ \\
\hline
\end{tabular}

***,**, *Statistically significant coefficients at the 1,5 , and $10 \%$ level. Heteroskedasticity-robust standard errors in parentheses 


\subsubsection{Program A for SMEs' individual research projects}

The public subsidies granted under the two rounds of Program A show evidence of input additionality. Compared to firms not applying for public grants, subsidized firms had a significant increase in R\&D expenditure, total wages, and tangible investments. The impact on R\&D expenditure was statistically significant in both the short and medium terms, but appeared to be stronger three to five years after the acceptance of the submitted project. This is consistent with studies for Italy (Cerqua and Pellegrini 2014; Cerulli and Potì 2012) and other countries (Czarnitzki and Toole 2007; Diamond 1999; Koga 2005), which rejected the hypothesis that private $\mathrm{R} \& \mathrm{D}$ funding is crowded out by public $\mathrm{R} \& \mathrm{D}$ policies.

We found a short- and medium-term crowding-in effect on the total amount of wages, although the positive impact on tangible investments seemed to be short term only. Program A, however, was unsuccessful in fostering intangible investments, which showed a similar pattern for subsidized and non-subsidized firms. The positive impact on employment was consistent with the findings of Goolsbee (1998) and Wolff and Reinthaler (2008), and the differentiated impact on tangible and intangible investments was also documented by Cannone and Ughetto (2014) for R\&D subsidy programs in the Piedmont region in Italy.

Moving on to output variables, we confirmed an additional impact of subsidies under Program A, although this positive effect was weaker and, in some cases, uncertain. The program stimulated patenting activity and profitability in funded firms. The number of patents increased only in the medium term: this is consistent with the idea that patents require some years to be filed and published. Similar results were documented by Czarnitzki and Hussinger (2004) for subsidy policies in Germany. The profitability of treated firms increased both in the short term, immediately after the grants were paid, and in the medium term, when the effect became stronger. For sales, however, the results were weaker and contrasting: the beneficial impact of the subsidy policy was limited to the second round of Program A, and sales were unaffected in firms submitting to the first round. This finding is in line with Corsino et al. (2012), who documented a weak output effect on firms' turnover of place-based R\&D policies in the northern Italian province of Trento.

The economic impact of subsidies under Program A was sizeable. Unfortunately, we did not have information on the size of grants, so we were unable to identify the precise quantitative effect of the subsidy. However, we assessed the approximate magnitude of the subsidy effect by comparing the DID estimates with the mean values of the outcome variables or by looking at the trends in these variables. Considering, for example, the effect on input variables, DID estimates suggest that the increase in R\&D intensity in subsidized firms exceeds non-funded firms by 0.2 to $1 \%$. This effect is very strong if we consider that the average $R \& D$ intensity of funded firms is about $0.6 \%$.

Sizeable effects were also produced on wages and tangible investments. For wages, the "additionality effect" ranged from 71,000 to 305,000 euros, and the average amount of wages in treated firms was around one million euros. For tangible investments, the positive effect of the program was between 0.058 and $0.1 \%$, compared with an average increase in tangible investments for subsidized firms of $0.22 \%$. The impact of Program A on SMEs' outputs was also economically significant. The net effect of the program on profitability ranged from 2.06 to 3.23 , which is very high considering that the mean value of funded firms' ROE was 4.3. The effect on patents was between 0.012 and 0.079 , once again very substantial compared to the mean number of patents $(0.048)$.

\subsubsection{Program B for collaborative research projects}

Moving on to Program B, under which applicants were required to submit projects in collaboration with local universities, research centers, and other firms, DID estimates provided mixed evidence. The program was successful in fostering SMEs' R\&D expenditure in the short term and led to an increase in the total wages paid, both in the short and medium terms. The estimates indicate that the program had a positive additional effect of $0.3 \%$ on R\&D intensity and about 70,000 euros on total wages. Tangible and intangible investments of treated firms, however, showed a stronger negative trend than untreated firms. The reduction in tangible and intangible investments appears to be particularly significant compared to the mean values of the variables $(0.22$ for tangible investments and 0.75 for intangible investments) and to the reduction experienced by firms in the control group. This is consistent with the idea that participation in collaborative research projects with other firms and universities produces synergies with regard to the availability of tangible and intangible capital that 
allows each participant to economize on new investments. However, the negative impact of subsidies on tangible and intangible investment could also hide a crowding-out effect that mitigates the overall input additionality of Program B. It is therefore possible that the funded SMEs partially substituted public for private R\&D outlays.

With regard to output additionality, the impact of collaborative subsidies granted under Program B was somewhat less effective than the individual subsidies and seen more in the longer term. There was a decline in ROE in the short term but a strong increase in the medium term. Patents of treated and untreated firms, however, showed no statistically significant difference. This could be the result of strategic behavior among the funded firms, which increased their patenting activity in the period just before the start of the collaborative project to avoid problems of disclosure and appropriability with other research partners (see the robustness analysis below). Finally, sales of firms subsidized under program B did not show any improvement over unsubsidized firms.

\subsection{Extensions and robustness checks}

\subsubsection{Heterogeneity in collaborative research projects}

The evaluation analysis compared the average outcomes between firms granted subsidies and the control groups of unsubsidized firms. Program B, however, forced firms to cooperate in research projects with other firms and universities. The average treatment effect may fail to account for a possible heterogeneity in firms' performance between participants in the projects.

To investigate whether some firms benefited more than others from the collaborative subsidy, we replicated the DID analysis by distinguishing between different sub-groups of firms funded under Program B. A general caveat of this sub-group approach is that only a few firms were funded under Program B, so each sub-group included very few observations. This prevents us from generalizing our findings.

First, for each project, we distinguished firms with the best and worst performance. The results are shown in columns (1) and (2) of Table 4 and suggest that the effects of the collaborative subsidy are quite heterogeneous, especially for $R \& D$ expenditure, profitability and, partially, for patents. Here, the evidence for best performers suggested clear additionality, but results did not differ substantially for investments in tangible and intangible assets, wages, and sales.

Second, we distinguished participants according to whether they were the leader of the funded research project. Columns (3) and (4) show that the project leaders benefited more than other participants in terms of R\&D spending, which follows an additional trend only for the former. By contrast, project leaders had poorer performance on patents, suggesting that having coordinated the project application, they may behave strategically and anticipate patenting their innovations to limit information disclosure to partners (who show an additional patent activity).

Third, we classified firms by the type of projects in which they participated: (i) projects with more or fewer participants than the median and (ii) projects having a university as leader and project coordinated by a private firm. Columns (5) and (6) indicate that firms in projects with many partners have better performance on $R \& D$ expenditure and patenting than those with a low number of partners. This suggests that collaboration might have positive effects only if it involves a certain number of partners, even though there is little variation in the number of participants across funded projects (ranging between 4 and 9) and the results should therefore be interpreted with caution. Finally, firms participating in projects coordinated by universities (column 7) achieved better results in terms of patents, but firms in projects led by a private firm (column 8 ) had better results for R\&D additionality. This is consistent with Engel et al. (2016), who found that public subsidies had a stronger additionality on R\&D spending in firms involved in inter-firm collaborations than in projects with research centers.

\subsubsection{Matching procedure}

To check the robustness of the estimates reported in Table 2 with the matching method, we replicated our analysis by using the nearest-neighbor matching algorithm, one of the most frequently used matching techniques in the evaluation literature. In this procedure, each subsidized firm was matched to the non-subsidized firms with the closest propensity score. For our test, we ran matching without replacement and with five nearest neighbors for each treated unit. Table 13 in the Appendix shows the DID results based on this matching method. 


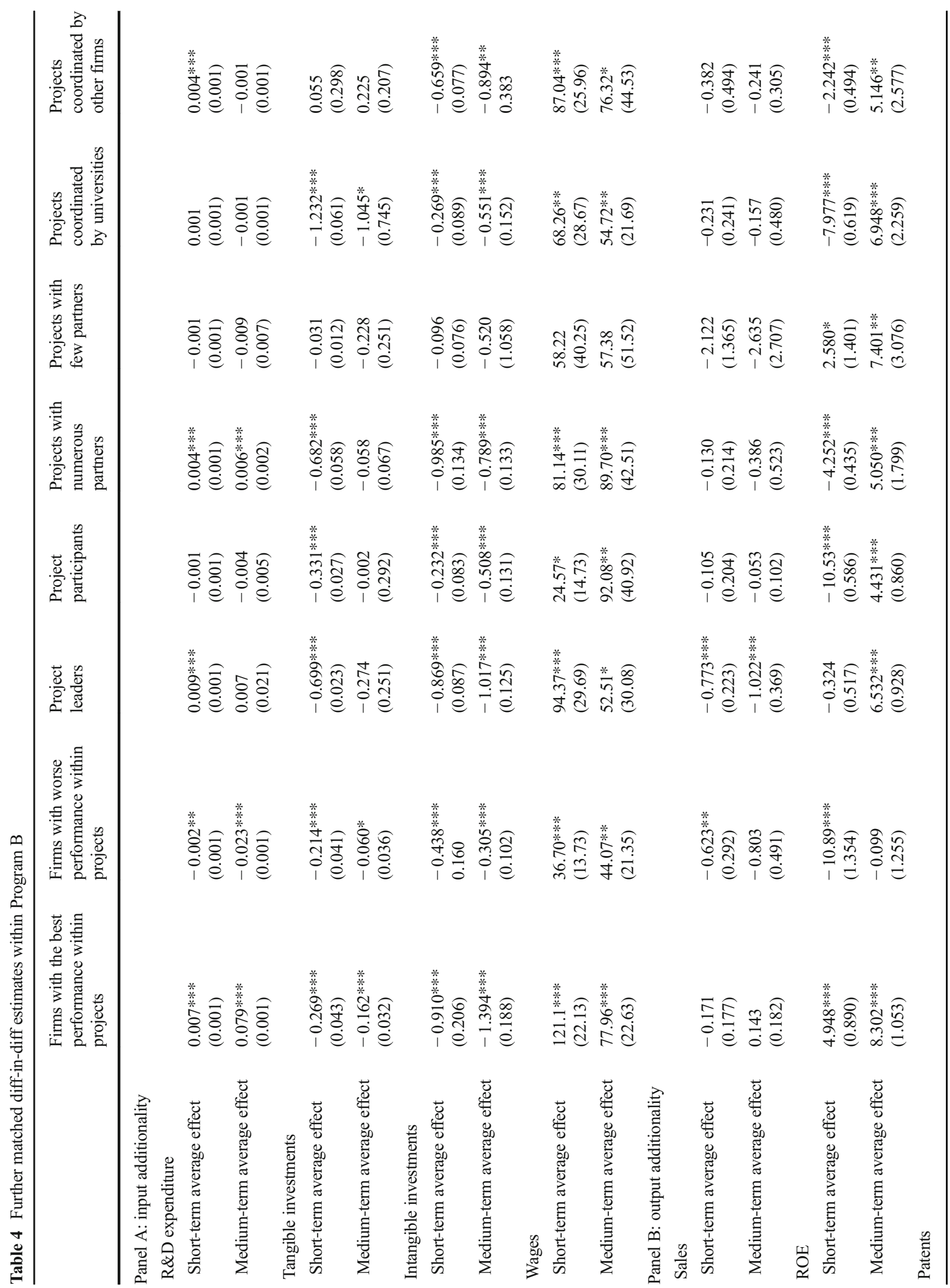


In general, the statistical significance was lower and the estimates were more volatile than those obtained using kernel matching. The negative effects of Program $\mathrm{B}$ on tangible and intangible investments were less pronounced, as were the positive effects of Program A on wages and, partially, on R\&D expenditure. Overall, however, the results were in line with the main analysis, corroborating our conclusions about a greater input additionality of subsidies to individual research projects.

\subsubsection{DID estimates}

DID relies on the main assumption that, in the absence of the program, the outcome in the treatment group would have followed the same trend as the outcome in the control group. In other words, the outcome should increase or decrease at the same rate in both groups. If outcome trends are different between the two groups of units, then DID estimates would be biased. Gertler et al. (2011) suggested that the validity of this equal trends assumption can be assessed by comparing changes in the outcome variables for the treatment and control groups in the years before the programs. The first program started in 2005 , so we used 2003 and 2004 to calculate the changes in the outcome variables. However, for the first round of Program A, we could not test the assumption for tangible and intangible investments, because both variables were computed as growth rate between two consecutive years, so before public funding, we had only one value/year.

Table 5 summarizes the results of the test. Overall, before the programs, the various outcomes did not significantly differ for treatment and control groups. This was particularly true for the first round of Program A, where outcome differences were all non-significant. However, for the second round of Program A and for Program B, subsidized and unsubsidized firms showed different trends in the number of patent applications, and subsidized firms were more patent-active than their nonsubsidized counterparts. This may have important implications for Program B, which encouraged R\&D cooperation. It is possible that subsidized firms increased their patenting just before the receipt of grant to avoid any problems of intellectual property rights with the other partners in the research projects.

The outcome variables in our sample showed relevant changes over time. These were particularly pronounced for input variables $(\mathrm{R} \& \mathrm{D}$ intensity and tangible and intangible investments) and for the number of patent applications. If the outcomes in a particular baseline year have a value far 
Table 5 Test on the equal trends assumption of DID

\begin{tabular}{clll}
\hline & $\begin{array}{l}\text { Program } \\
\text { A-2005 } \\
\text { (baseline }\end{array}$ & $\begin{array}{l}\text { Program } \\
\text { A-2007 } \\
\text { (baseline }\end{array}$ & $\begin{array}{l}\text { Program } \\
\text { B } \\
\text { (baseline }\end{array}$ \\
& $2004)$ & $2006)$ & $2007)$ \\
\hline R\&D & -0.001 & 0.001 & 0.002 \\
expenditure & $(0.001)$ & $(0.002)$ & $(0.002)$ \\
Tangible & - & -0.100 & -1.20 \\
investments & & $(0.072)$ & $(0.89)$ \\
Intangible & - & -0.072 & $-0.962^{*}$ \\
investments & & $(0.099)$ & $(0.544)$ \\
Wages & 83.4 & 41.3 & 89.3 \\
& $(61.9)$ & $(42.6)$ & $(58.5)$ \\
Sales & 0.042 & 0.446 & 0.140 \\
& $(0.477)$ & $(0.287)$ & $(0.255)$ \\
ROE & 1.54 & 2.54 & -0.179 \\
& $(1.38)$ & $(1.85)$ & $(1.117)$ \\
Patents & 0.007 & $0.030^{* *}$ & $0.022^{* *}$ \\
& $(0.08)$ & $(0.015)$ & $(0.011)$ \\
\hline
\end{tabular}

**, *Statistically significant coefficients at the 1,5 , and $10 \%$ level. Heteroskedasticity-robust standard errors in parentheses

from average, then DID results can be misleading. To avoid this problem, we replicated the main analysis using the two-year average before the program as a baseline value for each outcome. ${ }^{3}$ The results, shown in Table 6 , further corroborate the findings of the main analysis.

A further critical assumption underlying DID is that the program under evaluation is not based on preexisting differences in the outcome variables (Heckman et al. 1999). A common issue is the possible decrease/increase in outcome variables for treated units in the period prior to program entry. This effect is known as Ashenfelter's Dip because Ashenfelter (1978) first detected it in evaluating the impact of government training programs on participants' earnings. A similar problem may arise in our analysis if firms receiving public support modified their R\&D strategies before the public program. For example, firms that apply for public subsidies may reduce $R \& D$ expenditure just before the program, hoping to finance their R\&D through public funding instead. Firms applying for public subsidies under the collaborative program may have increased their patent applications before the start of the program to avoid appropriability and disclosure issues with their future partners.

\footnotetext{
${ }^{3}$ We only had two years before the starting point of the first round of Program A, and tangible and intangible investments were computed as growth rate, so the check was not feasible for these variables.
}

Our results show that we can probably exclude the presence of an Ashenfelter's Dip effect in our sample. First, the outcome variables for the treated and control groups satisfied the parallel trend assumption before the program. If there was an Ashenfelter's Dip effect, the trends for these outcomes would be different in the two groups of firms. Second, the DID estimates obtained using the two-year average before the program as a baseline value of each outcome are similar to those obtained with only $t-1$ as a baseline year (see Table 4).

\subsubsection{Regression analysis}

Lastly, we verified the robustness of our results by using a regression-based approach. We implemented DID by using the fixed effect estimator and including matching variables as covariates. The estimates are reported in the Appendix (Table 14) and are consistent with the main findings of the analysis.

\section{Concluding remarks}

This paper has analyzed the effectiveness of two regional programs designed to support research and innovation in SMEs. These programs provide direct monetary grants for firms' research projects and were implemented by the government of the Marche region in Italy. The two programs had similar objectives and characteristics, with the only major difference being that one program focused on research projects in individual firms and the second on collaborative research projects between firms and universities. The two main research questions addressed by our evaluation analysis were whether regional public subsidies had input/output additionality effects and whether these effects were heterogeneous for the individual and collaborative programs.

Overall, the impact evaluation analysis indicated that both programs had positive effects on some important aspects of firms' R\&D activity, although these effects differed for the two programs. The programs granting individual research subsidies were successful in stimulating outcome variables related to $R \& D$ inputs of subsidized SMEs such as R\&D expenditure, employment, and tangible investments, in line with the input additionality hypothesis. Individual subsidies also had a positive impact on subsidized firms' performance, with an increase in profitability and patent applications over similar non-subsidized firms. By contrast, the 
Table 6 The effect of regional subsidies on firms' activity with averaged baseline matching variables

\begin{tabular}{|c|c|c|c|}
\hline & $\begin{array}{l}\text { Program A-2005 } \\
\text { (baseline 2004) }\end{array}$ & $\begin{array}{l}\text { Program A-2007 } \\
\text { (baseline 2006) }\end{array}$ & $\begin{array}{l}\text { Program B } \\
\text { (baseline 2007) }\end{array}$ \\
\hline \multicolumn{4}{|l|}{ Panel A: input additionality } \\
\hline \multicolumn{4}{|l|}{$\mathrm{R} \& \mathrm{D}$ expenditure } \\
\hline Short-term average effect & $\begin{array}{l}0.002 \\
(0.001)\end{array}$ & $\begin{array}{l}0.003 * * \\
(0.001)\end{array}$ & $\begin{array}{l}0.011 * * * \\
(0.002)\end{array}$ \\
\hline Medium-term average effect & $\begin{array}{l}0.009 * * * \\
(0.002)\end{array}$ & $\begin{array}{l}0.006 * * * \\
(0.001)\end{array}$ & $\begin{array}{l}0.007 * * * \\
(0.002)\end{array}$ \\
\hline \multicolumn{4}{|l|}{ Tangible investments } \\
\hline Short-term average effect & - & $\begin{array}{l}0.058^{*} \\
(0.048)\end{array}$ & $\begin{array}{l}-0.023 \\
(0.039)\end{array}$ \\
\hline Medium-term average effect & - & $\begin{array}{l}0.023 \\
(0.031)\end{array}$ & $\begin{array}{l}0.434 \\
(0.374)\end{array}$ \\
\hline \multicolumn{4}{|l|}{ Intangible investments } \\
\hline Short-term average effect & - & $\begin{array}{l}0.005 \\
(0.151)\end{array}$ & $\begin{array}{l}0.186 \\
(0.126)\end{array}$ \\
\hline Medium-term average effect & - & $\begin{array}{l}-0.278 \\
(0.138)\end{array}$ & $\begin{array}{l}0.090 \\
(0.132)\end{array}$ \\
\hline \multicolumn{4}{|l|}{ Wages } \\
\hline Short-term average effect & $\begin{array}{l}89.5 \\
(58.6)\end{array}$ & $\begin{array}{l}107.3 * * * \\
(37.6)\end{array}$ & $\begin{array}{l}202.6^{* * * *} \\
(37.4)\end{array}$ \\
\hline Medium-term average effect & $\begin{array}{l}317.2 * * * \\
(56.7)\end{array}$ & $\begin{array}{l}164.7 * * * \\
(36.2)\end{array}$ & $\begin{array}{l}188.2 * * * \\
(34.6)\end{array}$ \\
\hline \multicolumn{4}{|l|}{ Panel B: output additionality } \\
\hline \multicolumn{4}{|l|}{ Sales } \\
\hline Short-term average effect & $\begin{array}{l}0.732 \\
(0.456)\end{array}$ & $\begin{array}{l}0.726^{* *} \\
(0.310)\end{array}$ & $\begin{array}{l}-0.121 \\
(0.234)\end{array}$ \\
\hline Medium-term average effect & $\begin{array}{l}0.659 \\
(0.450)\end{array}$ & $\begin{array}{l}1.031 * * * \\
(0.317)\end{array}$ & $\begin{array}{l}-0.281 \\
(0.235)\end{array}$ \\
\hline \multicolumn{4}{|l|}{ ROE } \\
\hline Short-term average effect & $\begin{array}{l}1.788^{*} \\
(1.067)\end{array}$ & $\begin{array}{l}2.178^{* *} \\
(1.014)\end{array}$ & $\begin{array}{l}-3.205^{* * *} * \\
(1.068)\end{array}$ \\
\hline Medium-term average effect & $\begin{array}{l}0.582 \\
(1.115)\end{array}$ & $\begin{array}{l}2.639 * * * \\
(0.985)\end{array}$ & $\begin{array}{l}6.328 * * * \\
(0.865)\end{array}$ \\
\hline \multicolumn{4}{|l|}{ Patents } \\
\hline Short-term average effect & $\begin{array}{l}0.018 \\
(0.012)\end{array}$ & $\begin{array}{l}0.009 \\
(0.006)\end{array}$ & $\begin{array}{l}-0.003 \\
(0.003)\end{array}$ \\
\hline Medium-term average effect & $\begin{array}{l}0.092 * * * \\
(0.012)\end{array}$ & $\begin{array}{l}-0.007 \\
(0.005)\end{array}$ & $\begin{array}{l}-0.011 * * * \\
(0.001)\end{array}$ \\
\hline
\end{tabular}

***, **, *Statistically significant coefficients at the 1,5 , and $10 \%$ level. Heteroskedasticity-robust standard errors in parentheses. The twoyear average before the program is used as a baseline value for each outcome

program targeting collaborative research had additional effects on R\&D expenditure, employment, and profitability of subsidized firms, but also crowded out investments in tangible and intangible assets, casting some doubts on the overall input additionality of the collaborative program. Sales and patent applications of firms subsidized under Program B were not significantly different from other similar firms not receiving subsidies, confirming the scarcer additionality of public subsidies for collaborative R\&D projects. The effects of Program B were also unevenly distributed across project participants, engendering an additionality in R\&D expenditure for some firms and not for others.

Our findings indicated that public subsidies for R\&D were to some extent more effective if directed towards individual research projects. This should not, however, be interpreted as disputing the merit of recent regional innovation policies favoring R\&D cooperation. Instead, 
we suggest that public funding of $R \& D$ cooperation should carefully take into account the possible drawbacks of forced collaboration, particularly free-riding and moral hazard, and design appropriate schemes to foster the formation of real and effective research partnerships. Public programs for collaborative research are an important but complex instrument of innovation policy, and require an in-depth understanding of the incentives around spontaneous R\&D cooperation, and the divergent interests of the various partners.

The requirements imposed by the subsidy program studied on the formation of the research partnerships do not appear completely consistent with the characteristics of the local context. The program forces cooperation with regional universities, perhaps overlooking universities' orientation towards basic research, and not recognizing that local SMEs have a long tradition of interfirm cooperation but not of relationships with universities and research centers. They are therefore mainly interested in very applied research and commercializing the output of R\&D activities (Balloni and Iacobucci 2004; D'Este and Perkmann 2011).

Finally, our evaluation study had some limitations that call for future research. First, the empirical analysis was based on a binary indicator for public funding, and the effectiveness of subsidy programs could be better and more precisely estimated given full information on the size of subsidies received by each firm. Second, our evaluation analysis focused on input/output additionality, which may be not sufficient to assess the effectiveness of public programs for collaborative research. R\&D cooperation can have a more general impact on SMEs' R\&D strategy and particularly on their ability to assimilate and exploit external knowledge and the internal capabilities required for establishing further collaborations with firms and research centers. All these effects, identified by the literature under the broad concept of behavioral additionality (Buisseret et al. 1995), are particularly important for place-based innovation policies and need to be carefully taken into account in future research.

Acknowledgements We wish to thank Donato Iacobucci for providing us with data on the regional public programs that we analyze in this paper. A word of sincere appreciation also to Ornella Maietta for providing us data on the regional innovation system. We are grateful to Alfredo Del Monte, Peter Harasztosi, Benjamin Le Pendeven, Giulia Santangelo, and participants at the SIEPI (Milan, Italy) and ENTFIN (Lyon, France) conferences for their invaluable comments. The views expressed in this paper are those of the authors and do not necessarily reflect official views of the European Commission.

Funding Luca Pennacchio acknowledges the funding received from Parthenope University of Naples through the research grants "Bando di sostegno alla ricerca individuale per il triennio 20152017" (years 2016 and 2017) and "Bando di Ateneo per il sostegno alla partecipazione ai bandi di ricerca competitiva per il triennio 2016-2018."

\section{Appendix 1. The regional context and the programs under scrutiny}

The Appendix describes in detail the context of the Marche region and the two programs under scrutiny.

\section{The regional context}

Situated in Italy's center, Marche is one of the twenty NUTS2 regions in the country. It belongs to what has come to be called the "Third Italy," a group of regions that obtained high growth rates, thanks to a model of development based on small and medium-sized enterprises. Regional firms, typically clustered in industrial districts, are connected in integrated territorial systems by complex value chain relationships as well as by other types of formal and informal networks, which create a unique balance between inter-firm competition and cooperation. In the Marche region, the Italian Institute of Statistics (ISTAT) has surveyed 19 industrial districts where about $70 \%$ of the total regional workforce is employed, with about $75 \%$ of workers in manufacturing (Bank of Italy 2016).

Based on the survey on "Industry and Services" conducted by ISTAT in 2011, 78.9\% of manufacturing workers are employed in firms with fewer than 10 employees, $18.7 \%$ in firms with between 10 and 49 employees, and only $2.4 \%$ in firms with more than 50 employees.

The manufacturing system has been historically specialized in traditional industries at low and medium technological intensity, such as food, footwear and leather, furniture, machinery, and textile. Recently, however, more technology-intensive industries such as ICT and domotics are becoming increasingly important for the local economy (Alessandrini 2015; Iacobucci et al. 2015). In 2008, the Marche was the Italian region with the lowest level of specialization in hi-tech sectors $(2.1 \%$ compared to the national mean of $3.3 \%$ ). In 2013, however, although its level of specialization was still low with respect to the national average $(3.4 \%)$, the region recorded the best performance, rising from 2.1 to $2.7 \%$ (see Table 7). 
The low propensity of local firms for innovation is confirmed by the share of manufacturing firms that have introduced product/process innovations, which is significantly lower and decreasing (24.5\%) compared with the Italian average $(33.5 \%)$. In addition, local firms are relatively more inclined to introduce process innovations than product innovations: among firms with product/process innovations, the majority have introduced only process innovation (16.1\%), while a small part have introduced only product innovations (4.8\%); for Italy, the corresponding figures are 15.6 and $5.2 \%$, respectively. ${ }^{4}$

Similar indications come from the ratio between R\&D expenditure and GDP, which is well below the Italian average in all the years considered, especially for public institutions and private firms. The Marche region lags behind the Italian average also with respect to the number of employees in R\&D activities (3.1 per thousands of workers against an average value of 4 for Italy in 2012) and the number of researchers on total workforce ( 2 and $3 \%$, in the Marche and Italy, respectively). In general, local firms participate in formal collaborative agreements for R\&D to a lesser extent than do Italian firms: the percentage of innovative firms in the region that cooperate in R\&D activities with external partners is $29.1 \%$ against a countrywide average of $39.9 \%$. However, if we restrict the analysis on the collaborations with universities, local firms appear slightly more inclined towards cooperation than other Italian firms. Data drawn from the EFIGE database, in fact, indicate that $4.76 \%$ of innovative firms in the region has been engaged in cooperation with universities during the period 2007-2009, while at national level, the value was $4.24 \% .^{5}$ Overall, such figures are consistent with a model of innovation that has a weak propensity towards in-house R\&D, while being based on a widespread innovative capability produced by learning-bydoing processes, acquisition of existing knowledge from external sources and localized knowledge spillovers in industrial districts and value chain networks (Favaretto and Zanfei 2007).

Four public universities are located in the Marche and play an important role in the regional innovation

\footnotetext{
${ }^{4}$ Source: ISTAT, Indicatori Territoriali per le Politiche di Sviluppo (2015).

${ }^{5}$ The EU-EFIGE/Bruege-Unicredit dataset (http://bruegel. org/publications/datasets/efige/) provides survey data on a sample of almost 15,000 firms headquartered in seven European countries (Germany, France, Italy, Spain, UK, Austria, Hungary). Data refer to firms' international activities, innovation, labor organization, financing and organizational activities, and pricing behavior.
}

system, especially the pole of scientific faculties concentrated in the regional capital. Intramural R\&D expenditures of the universities are in line with the Italian mean (Table 7), while direct business ventures (academic spin-offs) with academic researchers from universities accounted for $4.4 \%$ of total spin-offs in Italy as of 2013 (Netval 2014; at the same date, academic researchers in the Marche region accounted for $2.6 \%$ of the national total). Besides universities, there are two public research institutions, the Institute of Marine Science and the Research Centre for Soil-Plant System Studies, which operate in the agriculture, forestry, and fishing sector. Lastly, there are no private centers for $\mathrm{R} \& \mathrm{D}$ activities but the region does have six centers for technology transfer, both public and in joint venture between public and the private sector.

2. The regional programs

Our empirical evaluation focuses on two subsidy programs implemented and managed by the Marche Regional Authority and funded by the European Regional Development Fund. The aim of these programs is to promote $\mathrm{R} \& \mathrm{D}$ investments of local SMEs, leading to the introduction of radical and incremental product/ process innovations. The programs provide for the granting of financial subsidies to companies for their industrial research and the launch of experimental activities. Eligible firms belong to specific industrial sectors considered of strategic importance for the local economy. Such sectors range from traditional industries (e.g., food or apparel) to more technology-intensive ones (e.g., ICT, nanotechnology, building automation, new materials).

The first program (hereafter, Program A) targets small and medium-sized enterprises headquartered in the region. The definition of SMEs is based on the number of employees (less than 250) and the turnover (below $€ 50$ million) or total assets (below $€ 43$ million). In addition, eligible firms cannot receive other public subsidies (regional, national, or European) for R\&D. This incompatibility is very helpful to our investigation as it excludes a major confounding factor and helps identify the causal effect of the regional program under scrutiny on the R\&D input and output of recipient firms.

Under Program A, firms can submit a research project either individually or in cooperation with other firms, universities, public research institutes, science parks, and technology transfer centers. Despite this opportunity to 
Table 7 Descriptive statistics of regional innovation systems in selected years (\%)

\begin{tabular}{|c|c|c|c|c|c|c|}
\hline & \multicolumn{2}{|l|}{2008} & \multicolumn{2}{|l|}{2012} & \multicolumn{2}{|l|}{2013} \\
\hline & Marche & Italy & Marche & Italy & Marche & Italy \\
\hline Specialization in sectors at high knowledge intensity* & 2.1 & 3.3 & 2.6 & 3.3 & 2.7 & 3.4 \\
\hline Rate of innovation of manufacturing firms** & 29.7 & 30.7 & 24.5 & 33.5 & & - \\
\hline Rate of cooperation of innovative firms*** & - & & 29.1 & 39.9 & & - \\
\hline Rate of cooperation of innovative firms with universities and R\&D centers**** & 4.76 & 4.24 & & & & \\
\hline $\mathrm{R} \& \mathrm{D}$ expenditure on GDP, total $* * * * *$ & 0.74 & 1.16 & 0.81 & 1.27 & 0.83 & 1.31 \\
\hline Private sector & 0.35 & 0.62 & 0.41 & 0.69 & 0.43 & 0.72 \\
\hline Public institutions & 0.03 & 0.15 & 0.03 & 0.19 & 0.03 & 0.18 \\
\hline Universities & 0.35 & 0.35 & 0.36 & 0.36 & 0.36 & 0.37 \\
\hline
\end{tabular}

Source: our calculations based on ISTAT, Eurostat, and EFIGE data

* Percentage of employees on total workforce in hi-tech manufacture and service industries

** Share of manufacturing firms introducing product and/or process innovations

**** Percentage of innovative firms that cooperate in R\&D activities

***** Percentage of innovative firms that cooperated in R\&D activities with universities and other R\&D centers in the period 2007-2009

******* Total intramural $\mathrm{R} \& \mathrm{D}$ expenditure that is all expenditure for $\mathrm{R} \& \mathrm{D}$ performed within a sector, on GDP

collaborate with other actors, applications actually received under this subsidy program consist only of individual research projects. Funded projects have to start within one month of their acceptance and have to be terminated within 18 months. Costs eligible for subsidization include expenses for machinery, equipment and raw materials, purchases of software, patents and licenses, wages for recruited researchers, and fees for consultancy services. The total cost of the project has to be at least $€ 200,000$. The maximum non-repayable grant accounts for $35 \%$ of total costs of the project, while the maximum interest rate paid on the repayable subsidy is $10 \%$.

Like Program A, also the second type of subsidy program (hereafter, Program B) aims to foster the introduction of product and process innovation by firms headquartered in the region. However, under Program $\mathrm{B}$, eligible research projects are required mandatorily to be presented and carried out by four or more subjects, including at least three firms and one university or center for technology transfer in the Marche region. This program thus explicitly aims to stimulate innovation processes through knowledge creation and transfer among the actors involved in the regional innovation system. In order to ensure a real and effective collaboration among the subjects involved in the project, Program B specifies that $(i)$ each participating firm has to fund at least $15 \%$ of the total cost of the project and cannot sustain more than $70 \%$ of it; (ii) universities and centers for technology transfer involved in the projects must provide services or consultancy equal to at least $10 \%$ of the total cost of the project. Under Program B too, firms cannot accumulate the regional subsidy with other $\mathrm{R} \& \mathrm{D}$ grants from different sources.

It is worth noting that, although firm size is no longer a criterion of eligibility, most applicants are actually small and medium enterprises. Indeed, program B is also open to large firms but actually only 10 applicants have a turnover higher than the $€ 50$ million SME threshold. For the sake of comparison with Program A, we exclude these firms from the analysis. Under Program $\mathrm{B}$, approved projects have to start within one month of acceptance and their maximum duration is 24 months. The following expenditures are eligible for subsidy: employment (maximum $60 \%$ of total project costs);

Table 8 Descriptive statistics of regional programs (millions of euros)

\begin{tabular}{lccl}
\hline & $\begin{array}{l}\text { Program } \\
\text { A-2005 }\end{array}$ & $\begin{array}{l}\text { Program } \\
\text { A-2007 }\end{array}$ & $\begin{array}{l}\text { Program } \\
\text { B }\end{array}$ \\
\hline Total amount of grants & 15.3 & 28.4 & 15.5 \\
Projects funded & 103 & 179 & 47 \\
Projects not approved & 90 & 69 & 4 \\
$\begin{array}{l}\text { Admissible amount of projects } \\
\text { Min. }\end{array}$ & 0.1 & 0.2 & 0.25 \\
Max. & 1 & 2 & 2 \\
$\begin{array}{l}\text { Average amount of } \\
\text { funded projects }\end{array}$ & 0.185 & 0.212 & 1.440 \\
\hline
\end{tabular}


tangible goods (including machinery and equipment); intangible goods (including licenses and patents for a maximum of $40 \%$ of total project costs); general expenditure generated by the project (materials, administrative costs, etc.) not exceeding $10 \%$ of total project costs.

Under both Program A and Program B, a committee of independent experts appointed by the regional government decides on project approval and the assignment of grants. A number of criteria are explicitly used to evaluate the research projects, with particular emphasis on innovativeness and competitiveness, as well as the capacity to increase the employment of high-skilled workers.

Table 8 reports some descriptive statistics concerning the two programs. With regard to Program A, we analyze two rounds, the first taking place in 2005 and the second in 2007. Program B was launched and implemented in 2008. The size of the projects slightly differs between programs: it ranges between $€ 100,000$ and $€ 1,000,000$, for the first round of the Program A, between $€ 200,000$ and $€ 2,000,000$, for the second round of Program A, and between $€ 250,000$ and $€ 2,000,000$ for Program B. However, the average amount of the grants actually approved is very similar across the programs: $€ 185,000$ and $€ 212,000$ for projects funded under the two rounds of Program A, and $€ 1,440,000$ for those funded under Program B, where the average number of participants collaborating on a research project is approximately 4.5 . Considering that the targeted firms are small and medium size, the amount of the subsidies appears particularly substantial.

Looking at the number of submissions, it emerges that most of the projects submitted were approved and subsidized. The total number of applications to the two rounds of Program A amounted to 193 and 248, respectively, of which $103(54 \%)$ and 179 (72\%) were approved. Under Program B, out of 51 applications submitted, 47 (92\%) were approved and 4 rejected.

The distribution of funded firms by industry in accordance with the NACE Rev. 2 classification is reported in Table 9. Firms belong both to traditional sectors, in line with the specialization of the local economy, and to some technology-intensive sectors (e.g., computer and

Table 9 Subsidized firms by sector of activity

\begin{tabular}{|c|c|c|c|c|}
\hline $\begin{array}{l}\text { NACE Rev. } 2 \\
\text { code }\end{array}$ & Description & $\begin{array}{l}\text { Program } \\
A-2005 \\
(n=78)\end{array}$ & $\begin{array}{l}\text { Program } \\
\mathrm{A}-2007 \\
(n=98)\end{array}$ & $\begin{array}{l}\text { Program } \\
\mathrm{B} \\
(n=62)\end{array}$ \\
\hline $\mathrm{CA}$ & Food products, beverages, and tobacco products & - & 4.08 & 1.61 \\
\hline $\mathrm{CB}$ & Textiles, apparel, leather, and related products & 7.79 & 4.08 & 8.06 \\
\hline $\mathrm{CC}$ & Wood and paper product and printing & 1.30 & 3.06 & - \\
\hline $\mathrm{CE}$ & Chemicals and chemical products & - & 8.16 & - \\
\hline CG & Rubber and plastics products and other non-metallic mineral products & 9.09 & 9.18 & 11.29 \\
\hline $\mathrm{CH}$ & Basic metals and fabricated metal products, except machinery and equipment & 15.59 & 11.24 & 11.29 \\
\hline CI & Computer, electronic and optical products & 12.99 & 5.10 & 12.90 \\
\hline CJ & Electrical equipment & 5.19 & 5.10 & 6.45 \\
\hline $\mathrm{CK}$ & Machinery and equipment nec & 23.36 & 11.24 & 19.36 \\
\hline CL & Transport equipment & 1.30 & 1.02 & 3.23 \\
\hline $\mathrm{CM}$ & Other manufacturing, repair and installation of machinery and equipment & 9.09 & 11.22 & 6.45 \\
\hline $\mathrm{D}$ & Electricity, gas, steam and air-conditioning supply & 1.30 & - & 3.23 \\
\hline $\mathrm{E}$ & Water supply, sewerage, waste management, and remediation & 1.30 & 1.02 & - \\
\hline $\mathrm{F}$ & Construction & 3.90 & 5.10 & 4.84 \\
\hline G & Wholesale and retail trade, repair of motor vehicles and motorcycles & 1.30 & 7.14 & 4.84 \\
\hline JA & Publishing, audiovisual and broadcasting activities & - & 1.02 & - \\
\hline $\mathrm{K}$ & IT and other information services & 2.60 & 11.22 & 4.84 \\
\hline $\mathrm{L}$ & Real estate activities & 1.30 & 1.02 & - \\
\hline MA & $\begin{array}{l}\text { Legal, accounting, management, architecture, engineering, technical testing and } \\
\text { analysis activities }\end{array}$ & 1.30 & - & 1.61 \\
\hline \multirow[t]{2}{*}{ MB } & Scientific research and development & 1.30 & - & - \\
\hline & Total & 100 & 100 & 100 \\
\hline
\end{tabular}


electronic products, machinery and equipment). It is worth noting that the distribution of firms across sectors is quite homogeneous between the two programs, facilitating the comparison of the two programs' design.

\section{Appendix 2 The full set of DID results}

The Appendix shows in detail the main results of the impact evaluation analysis summarized in Table 9 of the paper.

Table 10 The effect of regional subsidies on firms' activity: Program A -2005

\begin{tabular}{|c|c|c|c|c|c|c|c|}
\hline & \multicolumn{3}{|c|}{ During the project } & \multicolumn{4}{|c|}{ After the project } \\
\hline & $t 1$ & $t 2$ & Average & $t 1$ & $t 2$ & $t 3$ & Average \\
\hline $\mathrm{R} \& \mathrm{D}$ expenditure & $\begin{array}{l}0.002 \\
(0.002)\end{array}$ & $\begin{array}{l}0.002 \\
(0.002)\end{array}$ & $\begin{array}{l}0.002 * \\
(0.001)\end{array}$ & $\begin{array}{l}0.004 * * * \\
(0.002)\end{array}$ & $\begin{array}{l}0.009 * * * \\
(0.002)\end{array}$ & $\begin{array}{l}0.017 * * * \\
(0.003)\end{array}$ & $\begin{array}{l}0.010 \text { *** } \\
(0.002)\end{array}$ \\
\hline Tangible investments & $\begin{array}{l}0.016 \\
(0.049)\end{array}$ & $\begin{array}{l}0.199 * * * \\
(0.056)\end{array}$ & $\begin{array}{l}0.107 * * \\
(0.049)\end{array}$ & $\begin{array}{l}0.029 \\
(0.039)\end{array}$ & $\begin{array}{c}-0.022 \\
(0.059)\end{array}$ & $\begin{array}{l}0.055 \\
(0.038)\end{array}$ & $\begin{array}{l}0.020 \\
(0.041)\end{array}$ \\
\hline Intangible investments & $\begin{array}{l}0.912 * * * \\
(0.202)\end{array}$ & $\begin{array}{l}-0.388^{* *} \\
(0.183)\end{array}$ & $\begin{array}{l}0.258 \\
(0.170)\end{array}$ & $\begin{array}{l}0.020 \\
(0.187)\end{array}$ & $\begin{array}{l}0.134 \\
(0.192)\end{array}$ & $\begin{array}{l}-0.499 * * * \\
(0.163)\end{array}$ & $\begin{array}{c}-0.114 \\
(0.146)\end{array}$ \\
\hline Wages & $\begin{array}{l}20.8 \\
(57.4)\end{array}$ & $\begin{array}{l}160.9 * * * \\
(58.4)\end{array}$ & $\begin{array}{l}90.9^{*} \\
(50.4)\end{array}$ & $\begin{array}{l}249.1 * * * \\
(59.2)\end{array}$ & $\begin{array}{l}356.3 * * * \\
(59.2)\end{array}$ & $\begin{array}{l}312.2 * * * \\
(59.3)\end{array}$ & $\begin{array}{l}305.6^{* * * *} \\
(49.2)\end{array}$ \\
\hline Sales & $\begin{array}{l}0.100 \\
(0.429)\end{array}$ & $\begin{array}{l}0.805^{*} \\
(0.453)\end{array}$ & $\begin{array}{l}0.452 \\
(0.386)\end{array}$ & $\begin{array}{l}0.869 * \\
(0.466)\end{array}$ & $\begin{array}{l}0.350 \\
(0.471)\end{array}$ & $\begin{array}{c}-0.490 \\
(0.435)\end{array}$ & $\begin{array}{l}0.239 \\
(0.386)\end{array}$ \\
\hline ROE & $\begin{array}{l}4.303 * * * \\
(1.110)\end{array}$ & $\begin{array}{l}0.225 \\
(1.128)\end{array}$ & $\begin{array}{l}2.064 * * \\
(0.969)\end{array}$ & $\begin{array}{l}1.228 \\
(1.169)\end{array}$ & $\begin{array}{l}-0.527 \\
(1.153)\end{array}$ & $\begin{array}{l}0.192 \\
(1.126)\end{array}$ & $\begin{array}{l}0.270 \\
(0.916)\end{array}$ \\
\hline Patents & $\begin{array}{l}-0.078 * * * \\
(0.015)\end{array}$ & $\begin{array}{l}0.087 * * * \\
(0.013)\end{array}$ & $\begin{array}{l}0.005 \\
(0.013)\end{array}$ & $\begin{array}{l}0.072 * * * \\
(0.016)\end{array}$ & $\begin{array}{l}0.164 * * * \\
(0.016)\end{array}$ & $\begin{array}{l}0.000 \\
(0.009)\end{array}$ & $\begin{array}{l}0.079 * * * \\
(0.012)\end{array}$ \\
\hline
\end{tabular}

***, **, *Statistically significant coefficients at 1, 5, and $10 \%$ level. Heteroskedasticity-robust standard errors in parentheses

Table 11 The effect of regional subsidies on firms' activity: Program A-2007

\begin{tabular}{|c|c|c|c|c|c|c|c|}
\hline & \multicolumn{3}{|c|}{ During the project } & \multicolumn{4}{|c|}{ After the project } \\
\hline & $t 1$ & $t 2$ & Average & $t 1$ & $t 2$ & $t 3$ & Average \\
\hline R\&D expenditure & $\begin{array}{l}0.001 * \\
(0.001)\end{array}$ & $\begin{array}{l}0.002 * * \\
(0.001)\end{array}$ & $\begin{array}{l}0.002 * * \\
(0.001)\end{array}$ & $\begin{array}{l}0.006 * * * \\
(0.001)\end{array}$ & $\begin{array}{l}0.007 * * * \\
(0.001)\end{array}$ & $0.004 * * *(0.001)$ & $\begin{array}{l}0.005 * * * \\
(0.001)\end{array}$ \\
\hline Tangible investments & $\begin{array}{l}0.043 \\
(0.043)\end{array}$ & $\begin{array}{l}0.089 * \\
(0.054)\end{array}$ & $\begin{array}{l}0.058^{*} \\
(0.048)\end{array}$ & $\begin{array}{l}-0.003 \\
(0.032)\end{array}$ & $\begin{array}{l}-0.012 \\
(0.032)\end{array}$ & $\begin{array}{l}0.027 \\
(0.029)\end{array}$ & $\begin{array}{l}0.004 \\
(0.029)\end{array}$ \\
\hline Intangible investments & $\begin{array}{l}0.025 \\
(0.147)\end{array}$ & $\begin{array}{c}-0.093 \\
(0.138)\end{array}$ & $\begin{array}{c}-0.033 \\
(0.129)\end{array}$ & $\begin{array}{l}-0.268 * * \\
(0.137)\end{array}$ & $\begin{array}{c}-0.068 \\
(0.139)\end{array}$ & $\begin{array}{c}-0.048 \\
(0.145)\end{array}$ & $\begin{array}{c}-0.128 \\
(0.120)\end{array}$ \\
\hline Wages & $\begin{array}{l}45.3 \\
(40.3)\end{array}$ & $\begin{array}{l}97.1 * * \\
(42.4)\end{array}$ & $\begin{array}{l}71.5^{* *} \\
(36.4)\end{array}$ & $\begin{array}{l}123.3^{* * * *} \\
(41.1)\end{array}$ & $\begin{array}{l}132.5 * * * \\
(42.0)\end{array}$ & $\begin{array}{l}179.1 * * * \\
(41.4)\end{array}$ & $\begin{array}{l}144.5^{* * * *} \\
(34.4)\end{array}$ \\
\hline Sales & $\begin{array}{l}0.540 \\
(0.329)\end{array}$ & $\begin{array}{l}0.466 \\
(0.339)\end{array}$ & $\begin{array}{l}0.503 * \\
(0.297)\end{array}$ & $\begin{array}{l}-0.249 \\
(0.314)\end{array}$ & $\begin{array}{l}0.492 \\
(0.342)\end{array}$ & $\begin{array}{l}1.364 * * * \\
(0.372)\end{array}$ & $\begin{array}{l}0.531 * \\
(0.293)\end{array}$ \\
\hline ROE & $\begin{array}{l}4.784 * * * \\
(1.194)\end{array}$ & $\begin{array}{l}0.469 \\
(1.170)\end{array}$ & $\begin{array}{l}2.623 * * \\
(1.028)\end{array}$ & $\begin{array}{l}0.508 \\
(1.240)\end{array}$ & $\begin{array}{l}2.218 * \\
(1.166)\end{array}$ & $\begin{array}{l}7.052 * * * \\
(1.143)\end{array}$ & $\begin{array}{l}3.233 * * * \\
(0.962)\end{array}$ \\
\hline Patents & $\begin{array}{l}0.005 \\
(0.008)\end{array}$ & $\begin{array}{l}0.012 * \\
(0.007)\end{array}$ & $\begin{array}{l}0.008 \\
(0.006)\end{array}$ & $\begin{array}{l}0.008 \\
(0.006)\end{array}$ & $\begin{array}{l}0.015^{*} \\
(0.009)\end{array}$ & $\begin{array}{l}0.014 * * \\
(0.007)\end{array}$ & $\begin{array}{l}0.012 * \\
0.007\end{array}$ \\
\hline
\end{tabular}

$* * *, * *, *$ Statistically significant coefficients at 1,5 , and $10 \%$ level. Heteroskedasticity-robust standard errors in parentheses 
Table 12 The effect of regional subsidies on firms' activity: Program B

\begin{tabular}{|c|c|c|c|c|c|c|c|}
\hline & \multicolumn{3}{|c|}{ During the project } & \multicolumn{4}{|c|}{ After the project } \\
\hline & $t 1$ & $t 2$ & Average & $t 1$ & $t 2$ & $t 3$ & Average \\
\hline R\&D expenditure & $\begin{array}{l}0.001 \\
(0.001)\end{array}$ & $\begin{array}{l}0.005 * * * \\
(0.002)\end{array}$ & $\begin{array}{l}0.003^{* * * *} \\
(0.001)\end{array}$ & $\begin{array}{l}0.001 \\
(0.001)\end{array}$ & $\begin{array}{l}0.002 \\
(0.002)\end{array}$ & $\begin{array}{l}-0.006^{* * * *} \\
(0.001)\end{array}$ & $\begin{array}{l}-0.001 \\
(0.001)\end{array}$ \\
\hline Tangible investments & $\begin{array}{l}-0.547 * * * \\
(0.079)\end{array}$ & $\begin{array}{l}-0.415^{* * *} \\
(0.074)\end{array}$ & $\begin{array}{l}-0.484 * * * \\
(0.059)\end{array}$ & $\begin{array}{l}0.204^{* *} \\
(0.101)\end{array}$ & $\begin{array}{l}0.074 \\
(0.097)\end{array}$ & $\begin{array}{l}-0.485^{* * * *} \\
(0.078)\end{array}$ & $\begin{array}{l}-0.064 \\
(0.073)\end{array}$ \\
\hline Intangible investments & $\begin{array}{l}-0.607 * * * \\
(0.167)\end{array}$ & $\begin{array}{l}-0.427 * * \\
(0.179)\end{array}$ & $\begin{array}{l}-0.519 * * * \\
(0.142)\end{array}$ & $\begin{array}{l}-0.540 * * * \\
(0.181)\end{array}$ & $\begin{array}{l}-0.373 * * \\
(0.180)\end{array}$ & $\begin{array}{l}-0.992 * * \\
(0.173)\end{array}$ & $\begin{array}{l}-0.631 * * * \\
(0.132)\end{array}$ \\
\hline Wages & $\begin{array}{l}111.0 * * * \\
(35.7)\end{array}$ & $\begin{array}{l}46.6 \\
(33.6)\end{array}$ & $\begin{array}{l}79.6^{* * * *} \\
(29.2)\end{array}$ & $\begin{array}{l}68.4 * * \\
(33.9)\end{array}$ & $\begin{array}{l}89.7 * * \\
(35.2)\end{array}$ & $\begin{array}{l}47.1 \\
(36.4)\end{array}$ & $\begin{array}{l}69.4 * * \\
(27.2)\end{array}$ \\
\hline Sales & $\begin{array}{l}0.027 \\
(0.250)\end{array}$ & $\begin{array}{l}-0.518^{* *} \\
(0.236)\end{array}$ & $\begin{array}{l}-0.248 \\
(0.210)\end{array}$ & $\begin{array}{l}-0.292 \\
(0.251)\end{array}$ & $\begin{array}{l}-0.342 \\
(0.252)\end{array}$ & $\begin{array}{l}-0.387 \\
(0.263)\end{array}$ & $\begin{array}{l}-0.339 \\
(0.209)\end{array}$ \\
\hline ROE & $\begin{array}{l}-5.308 * * * \\
(1.163)\end{array}$ & $\begin{array}{l}-0.685 \\
(1.188)\end{array}$ & $\begin{array}{l}-3.026^{* * * *} \\
(1.030)\end{array}$ & $\begin{array}{l}7.093 * * * \\
(1.058)\end{array}$ & $\begin{array}{l}3.503 * * * \\
(1.110)\end{array}$ & $\begin{array}{l}7.780 * * * \\
(1.152)\end{array}$ & $\begin{array}{l}6.072 * * * \\
(0.875)\end{array}$ \\
\hline Patents & $\begin{array}{l}-0.003 \\
0.003\end{array}$ & $\begin{array}{l}0.020^{*} \\
(0.012)\end{array}$ & $\begin{array}{l}0.009 \\
(0.007)\end{array}$ & $\begin{array}{l}0.01 \\
(0.01)\end{array}$ & $\begin{array}{l}-0.001 \\
(0.002)\end{array}$ & $\begin{array}{l}0.002 \\
(0.002)\end{array}$ & $\begin{array}{l}0.001 \\
(0.002)\end{array}$ \\
\hline
\end{tabular}

***, **, *Statistically significant coefficients at 1, 5, and $10 \%$ level. Heteroskedasticity-robust standard errors in parentheses 


\section{Appendix 3 Further robustness results}

The Appendix shows the further robustness checks of the main analysis presented in the paper and described in sub-sections 4.3.2 and 4.3.3.

Table 13 The effect of regional subsidies on firms' activity - results with NN matching

Program A-2005

(baseline 2004)
Program A-2007

(baseline 2006)
Program B (baseline 2007)

R\&D expenditure

Short-term average effect

0.001

(0.002)

Medium-term average effect

$0.008 *$

$(0.005)$

Tangible investments

Short-term average effect

$$
\begin{aligned}
& 0.091 * \\
& (0.048) \\
& 0.011 \\
& (0.013)
\end{aligned}
$$

Medium-term average effect

0.182

(0.656)

0.039

(0.590)

\subsection{8}

(34.93)

$117.1 * *$

(56.6)

$$
\begin{aligned}
& 0.991 \\
& (0.733) \\
& 1.45^{* *} \\
& (0.72)
\end{aligned}
$$

$5.24 *$

(3.04)

0.647

(0.484)

Medium-term average effect

Patents

Short-term average effect

Medium-term average effect
$0.003 *$

$(0.001)$

$0.001 * * *$

$0.003 * *$

$(0.001)$

(0.007)

$-0.000$

(0.010)

$0.199 *$

$-0.378 *$

$(0.221)$

0.216

(0.334)

(0.089)

0.025

(0.470)

$-0.326 *$

$(0.400)$

$-0.061$

$-0.597 *$

(0.443)

(0.337)

32.42

(37.48)

18.19

(31.57)

134.2*

(71.6)

(70.4)

$-0.581$

0.227

(0.574)

$-1.15$

(1.24)

$(0.52)$

$-3.53$

(3.40)

$7.58 *$

(4.23)

0.702
$(0.837)$

0.015

0.010

$(0.009)$

0.002

0.014

(0.003)

$$
0.005
$$

(0.036)

0.079 *

(0.048)

$* * *, * *, *$ Statistically significant coefficients at 1,5 , and $10 \%$ level. Heteroskedasticity-robust standard errors in parentheses 
Table 14 The effect of regional subsidies on firms' activity. Fixed effects estimates

\begin{tabular}{|c|c|c|c|}
\hline & $\begin{array}{l}\text { Program A-2005 } \\
\text { (baseline 2004) }\end{array}$ & $\begin{array}{l}\text { Program A-2007 } \\
\text { (baseline 2006) }\end{array}$ & $\begin{array}{l}\text { Program B } \\
\text { (baseline 2007) }\end{array}$ \\
\hline \multicolumn{4}{|l|}{ Panel A: input additionality } \\
\hline \multicolumn{4}{|l|}{$\mathrm{R} \& \mathrm{D}$ expenditure } \\
\hline Short-term average effect & $\begin{array}{l}0.002 \\
(0.002)\end{array}$ & $\begin{array}{l}0.002 * \\
(0.001)\end{array}$ & $\begin{array}{l}0.001 \\
(0.005)\end{array}$ \\
\hline Medium-term average effect & $\begin{array}{l}0.009 * * \\
(0.004)\end{array}$ & $\begin{array}{l}0.005^{* * * *} \\
(0.001)\end{array}$ & $\begin{array}{c}-0.001 \\
(0.007)\end{array}$ \\
\hline \multicolumn{4}{|l|}{ Tangible investments } \\
\hline Short-term average effect & $\begin{array}{l}0.034 \\
(0.078)\end{array}$ & $\begin{array}{l}0.016 \\
(0.080)\end{array}$ & $\begin{array}{l}-0.335^{*} \\
(0.190)\end{array}$ \\
\hline Medium-term average effect & $\begin{array}{l}0.026 \\
(0.089)\end{array}$ & $\begin{array}{l}0.062 * \\
(0.003)\end{array}$ & $\begin{array}{l}-0.301 \\
(0.244)\end{array}$ \\
\hline \multicolumn{4}{|l|}{ Intangible investments } \\
\hline Short-term average effect & $\begin{array}{l}0.208 \\
(0.489)\end{array}$ & $\begin{array}{l}-.0190 \\
(0.397)\end{array}$ & $\begin{array}{l}-0.455 \\
(0.388)\end{array}$ \\
\hline Medium-term average effect & $\begin{array}{l}-0.131 \\
(0.403)\end{array}$ & $\begin{array}{l}0.159 \\
(0.211)\end{array}$ & $\begin{array}{l}-0.661 * \\
(0.380)\end{array}$ \\
\hline \multicolumn{4}{|l|}{ Wages } \\
\hline Short-term average effect & $\begin{array}{l}35.6^{* * *} \\
(18.7)\end{array}$ & $\begin{array}{l}69.8^{* *} \\
(32.1)\end{array}$ & $\begin{array}{l}37.1 \\
(25.4)\end{array}$ \\
\hline Medium-term average effect & $\begin{array}{l}164.2 * * \\
(79.1)\end{array}$ & $\begin{array}{l}164.5^{* * * *} \\
(61.3)\end{array}$ & $\begin{array}{l}49.6 \\
(45.4)\end{array}$ \\
\hline \multicolumn{4}{|l|}{ Panel B: output additionality } \\
\hline \multicolumn{4}{|l|}{ Sales } \\
\hline Short-term average effect & $\begin{array}{l}0.147 \\
(0.485)\end{array}$ & $\begin{array}{l}0.413^{*} \\
(0.233)\end{array}$ & $\begin{array}{c}-0.426 \\
(0.442)\end{array}$ \\
\hline Medium-term average effect & $\begin{array}{l}0.413^{*} \\
(0.233)\end{array}$ & $\begin{array}{l}0.423 * \\
(0.253)\end{array}$ & $\begin{array}{c}-0.983 \\
(0.874))\end{array}$ \\
\hline \multicolumn{4}{|l|}{ ROE } \\
\hline Short-term average effect & $\begin{array}{l}2.103 * * \\
(0.991)\end{array}$ & $\begin{array}{l}2.52 * * * \\
(0.951)\end{array}$ & $\begin{array}{l}-4.199 \\
(4.900)\end{array}$ \\
\hline Medium-term average effect & $\begin{array}{l}0.199 \\
(0.275)\end{array}$ & $\begin{array}{l}2.742 * \\
(1.601)\end{array}$ & $\begin{array}{l}7.582 * \\
(4.034)\end{array}$ \\
\hline \multicolumn{4}{|l|}{ Patents } \\
\hline Short-term average effect & $\begin{array}{l}0.016 \\
(0.038)\end{array}$ & $\begin{array}{l}0.002 \\
(0.031)\end{array}$ & $\begin{array}{l}0.007 \\
(0.010)\end{array}$ \\
\hline Medium-term average effect & $\begin{array}{l}0.076^{*} \\
(0.042)\end{array}$ & $\begin{array}{l}0.055^{*} \\
(0.031)\end{array}$ & $\begin{array}{l}0.001 \\
(0.001)\end{array}$ \\
\hline
\end{tabular}

$* * *, * *, *$ Statistically significant coefficients at 1,5 , and $10 \%$ level. Heteroskedasticity-robust standard errors in parentheses 
Open Access This article is distributed under the terms of the Creative Commons Attribution 4.0 International License (http:// creativecommons.org/licenses/by/4.0/), which permits unrestricted use, distribution, and reproduction in any medium, provided you give appropriate credit to the original author(s) and the source, provide a link to the Creative Commons license, and indicate if changes were made.

\section{References}

Alessandrini, P. (2015). Rapporto Marche +20. Sviluppo nuovo senza fratture. Ancona: Regione Marche, http://www.regione. marche.it/Portals/0/Sviluppo/Rapporto_marche20.pdf.

Alessandrini, P., Presbitero, A. F., \& Zazzaro, A. (2010). Bank size or distance: what hampers innovation adoption by SMEs? Journal of Economic Geography, 10(6), 845-881. https://doi.org/10.1093/jeg/lbp055.

Almus, M., \& Czarnitzki, D. (2003). The effects of Public R\&D subsidies on firms' innovation activities: the case of Eastern Germany. Journal of Business \& Economic Statistics, 21(2), 226-236. https://doi.org/10.1198/073500103288618918.

Antonioli, D., Marzucchi, A., \& Montresor, S. (2014). Regional innovation policy and innovative behaviour: looking for additional effects. European Planning Studies, 22(1), 6483. https://doi.org/10.1080/09654313.2012.722977.

Ardovino, O., \& Pennacchio, L. (2014). Inter-firm R\&D cooperation in local innovation networks: the case of Italian technological districts. EERI Research Paper Series No. 09/2014.

Arora, A., \& Gambardella, A. (1994). Evaluating technological information and utilizing it. Journal of Economic Behavior and Organization, 24, 91-114. https://doi.org/10.1016/01672681(94)90055-8.

Arrow, K.J. (1962). Economic welfare and the allocation of resources to invention. In R.R. Nelson (ed.), The rate and direction of inventive activity: economic and social factors. Princeton University Press, Princeton.

Arvanitis, S., Sydow, N., \& Woerter, M. (2008). Is there any impact of university-industry knowledge transfer on innovation and productivity? An empirical analysis based on Swiss firm data. Review of Industrial Organization, 32(2), 77-94. https://doi.org/10.1007/s11151-008-9164-1.

Ashenfelter, O. (1978). Estimating the effect of training programs on earnings. The Review of Economics and Statistics, 60(1), 47-57. https://doi.org/10.2307/1924332.

Audretsch, D. B., Lehmann, E. E., \& Menter, M. (2016). Public cluster policy and new venture creation. Economia e Politica Industriale, 43, 357. https://doi.org/10.1007/s40812-0160050-9.

Azagra-Caro, J. M., Pardo, R., \& Rama, R. (2012). Not searching, but finding: how innovation shapes perceptions about universities and public research organizations. The Journal of Technology Transfer, 39(3), 454-471. https://doi.org/10.1007 /s10961-012-9297-0.

Balloni, V., Iacobucci, D. (2004). The role of medium-sized and large firms in the evolution of industrial districts. The case of Marche. In: Cainelli, G., Zoboli, R. (eds.), The evolution of industrial districts. Contributions to economics. Physica, Heidelberg. https://doi.org/10.1007/978-3-7908-2700-2_8.

Bank of Italy (2016). Economie regionali. L'economia delle regioni italiane nel 2015.

Bartelt, H., Malmberg, A., \& Maskell, P. (2002). Clusters and knowledge: regional buzz, global pipelines, and the process of knowledge creation. DRUID Working Paper 02-2012, Copenhagen.

Belderbos, R., Carree, M., \& Lokshin, B. (2004). Cooperative R\&D and firm performance. Research Policy, 33, 14771492. https://doi.org/10.1016/j.respol.2004.07.003.

Bellucci, A., \& Pennacchio, L. (2016). University knowledge and firm innovation: evidence from European countries. The Journal of Technology Transfer, 41(4), 730-752. https://doi. org/10.1007/s10961-015-9408-9.

Bernini, C., \& Pellegrini, G. (2011). How are growth and productivity in private firms affected by public subsidy? Evidence from a regional policy. Regional Science and Urban Economics, 41, 253-265. https://doi.org/10.1016/j. regsciurbeco.2011.01.005.

Bertamino, F., Bronzini, R., De Maggio, M., Revelli, D. (2016). Regional policies for innovation: the case of technology districts in Italy. Regional Studies, 1-14. https://doi. org/10.1080/00343404.2016.1255321.

Bérubé, C., \& Mohnen, P. (2009). Are firms that receive R\&D subsidies more innovative? Canadian Journal of Economics, 42(1), 206-225. https://doi.org/10.1111/j.15405982.2008.01505.x.

Branstetter, L., \& Sakakibara, M. (2002). When do research consortia work well and why? Evidence from Japanese panel data. The American Economic Review, 92(1), 143-159. https://doi.org/10.1257/000282802760015649.

Bronzini, R., \& Iachini, E. (2014). Are incentives for R\&D effective? Evidence from a regression discontinuity approach. American Economic Journal: Economic Policy, 6(4), 100 134. https://doi.org/10.1257/pol.6.4.100.

Bronzini, R., \& Piselli, P. (2016). The impact of R\&D subsidies on firm innovation. Research Policy, 44(2), 442-457. https://doi.org/10.1016/j.respol.2015.10.008.

Buisseret, T., Cameron, H., \& Georghiou, L. (1995). What difference does it make? Additionality in the public support of $\mathrm{R} \& \mathrm{D}$ in large firms. International Journal of Technology Management, 10, 587-600. https://doi.org/10.1504 /IJTM.1995.025644.

Busom, I., Corchuelo, B., \& Martınez-Ros, E. (2014). Tax incentives...or subsidies for business R\&D? Small Business Economics, 43(3), 571-596. https://doi.org/10.1007/s11187014-9569-1.

Cannone, G., \& Ughetto, E. (2014). Funding innovation at regional level: an analysis of e public policy intervention in the Piedmont region. Regional Studies, 48(2), 270-283. https://doi.org/10.1080/00343404.2011.653338.

Cerqua, A., \& Pellegrini, G. (2014). Do subsidies to private capital boost firms' growth? A multiple regression discontinuity design approach. Journal of Public Economics, 109, 114 126. https://doi.org/10.1016/j.jpubeco.2013.11.005.

Cerulli, G., \& Potì, B. (2012). Evaluating the robustness of the effect of public subsidies on firms' R\&D: an application to Italy. Journal of Applied Economics, 15(2), 287-320. https://doi.org/10.1016/S1514-0326(12)60013-0. 
Chesbrough, H. W. (2003). Open innovation: the new imperative for creating and profiting from technology. Boston: Harvard Business School Press ISBN: 1-57851-837-7.

Cohen, W. M., \& Levinthal, D. A. (1990). Absorptive capacity: a new perspective on learning and innovation. Administrative Science Quarterly, 35(1), 128-152. https://doi.org/10.2307 12393553.

Cooke, P. (1992). Regional innovation systems: comparative regulation in the new Europe. Geoforum, 23, 356-382. https://doi.org/10.1016/0016-7185(92)90048-9.

Corsino, M., Gabriele, R., \& Giunta, A. (2012). R\&D incentives: the effectiveness of a place-based policy. Roma Tre Working Papers no 169.

Costantini, V., Crespi, F., Martini, C., \& Pennacchio, L. (2015). Demand-pull and technology-push public support for ecoinnovation: the case of the biofuels sector. Research Policy, 44, 577-595. https://doi.org/10.1016/j.respol.2014.12.011.

Cowling, M. (2016). You can lead a firm to R\&D but can you make it innovate? UK evidence from SMEs, Small Business Economics, 46, 565-577. https://doi.org/10.1007/s11187016-9704-2.

Crescenzi, R., Rodriguez-Pose, A., \& Storper, M. (2007). The territorial dynamics of innovation: a Europe-United States comparative analysis. Journal of Economic Geography, 7, 673-709. https://doi.org/10.1093/jeg/lbm030.

Criscuolo, C., Martin, R., Overman, H., \& Van Reenen, J., (2016). The causal effects of an industrial policy. CEP Discussion Paper No. 1113.

Czarnitzki, D., \& Delanote, J. (2015). R\&D policies for young SMEs: input and output effects. Small Business Economics, 45(3), 465-485. https://doi.org/10.1007/s11187-015-9661-1.

Czarnitzki, D., \& Hussinger, K. (2004). The link between R\&D subsidies, R\&D spending and technological performance. ZEW Discussion Paper No. 056.

Czarnitzki, D., \& Toole, A. A. (2007). Business R\&D and the interplay of R\&D subsidies and product market uncertainty. Review of Industrial Organization, 31(3), 169-181. https://doi.org/10.1007/s11151-007-9152-x.

Czarnitzki, D., Ebersberger, B., \& Fier, A. (2007). The relationship between R\&D collaboration, subsidies and R\&D performance: empirical evidence from Finland and Germany. Journal of Applied Econometrics, 22(7), 1347-1366. https://doi.org/10.1002/jae.992.

D'Este, P., \& Patel, P. (2007). University-industry linkages in the UK: what are the factors underlying the variety of interactions with industy? Research Policy, 36, 1295-1313. https://doi.org/10.1016/j.respol.2007.05.002.

D’Este, P., \& Perkmann, M. (2011). Why do academics engage with industry? The entrepreneurial university and individual motivations. The Journal of Technology Transfer, 36(3), 316-339. https://doi.org/10.1007/s10961-010-9153-z.

David, P. A., Hall, B. H., \& Toole, A. A. (2000). Is public R\&D a complement or substitute for private $\mathrm{R} \& \mathrm{D}$ ? A review of econometric evidence. Research Policy, 29(4-5), 497-529. https://doi.org/10.1016/S0048-7333(99)00087-6.

Del Monte, A., di Paola, N., Pennacchio, L., Sirtori, E., \& Valentini, M. (2016). Valutazione delle politiche per la Ricerca e l'Innovazione. Progetto: "Supporto alle attività di valutazione del Quadro Strategico Nazionale 2007/2013”, Agenzia per la Coesione Territoriale.
Diamond, A. M. (1999). Does federal funding “crowd in" private funding of science. Contemporary Economic Policy, 17(4), 423-431. https://doi.org/10.1111/j.1465-7287.1999.tb00694.x.

Doh, S., \& Kim, B. (2014). Government support for SME innovations in the regional industries: the case of government financial support program in South Korea. Research Policy, 43, 1557-1569. https://doi.org/10.1016/j. respol.2014.05.001.

Duch, N., Montolio, D., \& Mediavilla, M. (2009). Evaluating the impact of public subsidies on a firm's performance: a twostage quasi-experimental approach. Investigaciones Regionales, 16, 143-165.

Edquist, C. (2005). Systems of innovation-perspectives and challenges. In J. Fagerberg, D. C. Mowery, \& R. R. Nelson (Eds.), The Oxford handbook of innovation. Oxford: Oxford University Press.

Engel, D., Rothgang, M., \& Eckl, V. (2016). Systemic aspects of R\&D policy subsidies for R\&D collaborations and their effects on private R\&D. Industry and Innovation, 23(2), 206-222. https://doi.org/10.1080/13662716.2016.1146127.

Etzkowitz, H., \& Leydesdorff, L. (2000). The dynamics of innovation: from National Systems and "mode 2" to a triple helix of university-industry-government relations. Research Policy, 29(2), 109-123. https://doi.org/10.1016/S0048-7333 (99)00055-4.

Falck, O., Heblich, S., \& Kipar, S. (2010). Industrial innovation: direct evidence from a cluster-oriented policy. Regional Science and Urban Economics, 40(6), 574-582. https://doi. org/10.1016/j.regsciurbeco.2010.03.007.

Favaretto, I., Zanfei, A. (2007). Ricerca e innovazione in un sistema a industrializzazione diffusa. Il caso delle Marche. Carocci Editore, Roma.

Foreman-Peck, J. (2013). Effectiveness and efficiency of SME innovation policy. Small Business Economics, 41(1), 55-70. https://doi.org/10.1007/s11187-012-9426-z.

Fritsch, M., \& Lukas, R. (2001). Who cooperates on R\&D. Research Policy, 30, 297-312. https://doi.org/10.1016 /S0048-7333(99)00115-8.

Gertler, P., Martinez, S., Premand, P., Rawlings, R. B., \& Vermeersch, C. M. J. (2011). Impact evaluation in practice. Washington, DC: World Bank. https://doi.org/10.1596/9781-4648-0779-4.

Giunta, A., Pericoli, F. M., \& Pierucci, E. (2016). Universityindustry collaboration in the biopharmaceuticals: the Italian case. The Journal of Technology Transfer, 41, 818-840. https://doi.org/10.1007/s10961-015-9402-2.

Gonzalez, X., \& Pazo, C. (2008). Do public subsidies stimulate private R\&D spending? Research Policy, 37(3), 371-389. https://doi.org/10.1016/j.respol.2007.10.009.

Goolsbee, A. (1998). Does government R\&D policy mainly benefit scientists and engineers? American Economic Review, 88(2), 298-302 http://www.jstor.org/stable/116937.

Griliches, Z. (1986). Productivity, R\&D, and the basic research at the firm level in the 1970's. American Economic Review, $76(1), 141-154$.

Griliches, Z. (1990). Patent statistics as economic indicator: a survey. Journal of Economic Literature, 28, 1661-1707.

Grimpe, C., \& Kaiser, U. (2010). Balancing internal and external knowledge acquisition: the gains and pains from $R \& D$ outsourcing. Journal of Management Studies, 47(8), 14831509. https://doi.org/10.1111/j.1467-6486.2010.00946.x. 
Gulati, R. (1995). Does familiarity breed trust? The implications of repeated ties for contractual choice in alliances. Academy of Management Journal, 38, 85-112. https://doi.org/10.2307 1256729.

Guzzini, E., \& Iacobucci, D. (2014). Ownership as R\&D incentive in business groups. Small Business Economics, 43(1), 119135. https://doi.org/10.1007/s11187-013-9529-1.

Hall, B. H. (2002). The financing of research and development. Oxford Review of Economic Policy, 18(1), 35-51. https://doi. org/10.1093/oxrep/18.1.35.

Hall, B.H., \& Lerner, J. (2010). The financing of $R \& D$ and innovation. In: B. H. Hall and N. Rosenberg (et al.), Handbook of the economics of innovation, vol. 1. Elsevier. ISBN: 9780444519955.

Hall, B., Link, A., Scott, J. (2000). Universities as research partners. National Bureau of Economic Research. Working paper $\mathrm{N}^{\circ}$ W7643.

Heckman, J., Lalonde, R., \& Jeffrey, S. (1999). The economics and econometrics of active labor market programs. In $\mathrm{O}$. Ashenfelter \& D. Card (Eds.), Handbook of labor economics (Vol. III). Amsterdam: North-Holland. https://doi. org/10.1016/S1573-4463(99)03012-6.

Hirano, K., Imbens, G. W., \& Ridder, G. (2003). Efficient estimation of average treatment effects using the estimated propensity score. Econometrica, 71(4), 622-641 http://www.jstor. org/stable/3211657.

Hottenrott, H., \& Lopes-Bento, C. (2014). (International) R\&D collaboration and SMEs: the effectiveness of targeted public R\&D support schemes. Research Policy, 43, 1055-1066. https://doi.org/10.1016/j.respol.2014.01.004.

Hottenrott, H. Lopes-Bento, C. (2016). R\&D partnerships and innovation performance: can there be too much of a good thing? Journal of Product Innovation Management. https://doi.org/10.1111/jpim.12311.

Iacobucci, D., Micozzi, A., \& Micozzi, F. (2015). Rapporto sull'imprenditorialità nelle Marche. Economia Marche, 34(2), 63-107.

ISTAT (2015). Indicatori Territoriali per le Politiche di Sviluppo.

Jaffe, A., \& Trajtenberg, M. (2002). Patents, citations, and innovations: a window on the knowledge economy. Cambridge: MIT Press ISBN: 9780262100953.

Kang, K. N., \& Park, H. (2012). Influence of government R\&D support and inter-firm collaborations on innovation in Korean biotechnology SMEs. Technovation, 31, 68-78. https://doi.org/10.1016/j.technovation.2011.08.004.

Karhunen, H., \& Huovari, J. (2015). R\&D subsidies and productivity in SMEs. Small Business Economics, 45(4), 805-823. https://doi.org/10.1007/s11187-015-9658-9.

Khandker, S. R., Koolwal, G. B., \& Samad, H. A. (2010). Handbook of impact evaluation: quantitative methods and practices. Washington, DC: The World Bank. https://doi. org/10.1596/978-0-8213-8028-4.

Klette, T. J., \& Møen, J. (2011). R\&D investment responses to $R \& D$ subsidies: a theoretical analysis and a microeconomic study. Norwegian School of Economics and Business Administration, Working Paper.

Klette, T. J., Møen, J., \& Griliches, Z. (2000). Do subsidies to commercial R\&D reduce market failures? Microeconometric evaluation studies. Research Policy, 29(4-5), 471-495. https://doi.org/10.1016/S0048-7333(99)00086-4.
Klevorick, A. K., Levin, R. C., Nelson, R. R., \& Winter, S. G. (1995). On the sources and significance of interindustry differences in technological opportunities. Research Policy, 24, 185-205. https://doi.org/10.1016/0048-7333(93)00762I.

Koga, T. (2005). R\&D subsidy and self-financed R\&D: the case of Japanese high-technology start-ups. Small Business Economics, 24(1), 53-62. https://doi.org/10.1007/s11187005-3096-z.

Laursen, K., \& Salter, A. J. (2004). Searching low and high: why do firms cite universities as a source of innovation? Research Policy, 33, 1201-1215. https://doi.org/10.1016/j. respol.2004.07.004.

Laursen, K., \& Salter, A. J. (2014). The paradox of openness: appropriability, external search and collaboration. Research Policy, 43(5), 867-878. https://doi.org/10.1016/j. respol.2013.10.004.

Lavie, D., Stettner, U., \& Tushman, M. L. (2010). Exploration and exploitation within and across organizations. The Academy of Management Annals, 4(1), 109-155. https://doi.org/10.1080 /19416521003691287.

Lerner, J. (1999). The government as venture capitalist: the longrun impact of the SBIR program. The Journal of Business, 72(3), 285-318. https://doi.org/10.1086/209616.

Liberati, D., Marinucci, M., \& Tanzi, G. M. (2016). Science and technology parks in Italy: main features and analysis of their effects on the firms hosted. The Journal of Technology Transfer, 41(4), 694-729. https://doi.org/10.1007/s10961015-9397-8.

Lokshin, B., Hagedoorn, J., \& Letterie, W. (2011). The bumpy road of technology partnerships: understanding causes and consequences of partnership mal-functioning. Research Policy, 40(2), 297-308. https://doi.org/10.1016/j. respol.2010.10.008.

Lööf, H., \& Broström, A. (2008). Does knowledge diffusion between university and industry increase innovativeness? The Journal of Technology Transfer, 33(1), 73-90. https://doi.org/10.1007/s10961-006-9001-3.

Lundvall, B.-A. (Ed.). (1992). National systems of innovation: towards a theory of innovation and interactive learning. London: Pinter Publishers. https://doi.org/10.1080 /08109029308629360.

Martin, B. R. (2016). R\&D policy instruments - a critical review of what we do and don't know. Industry and Innovation, 23(2), 157-176. https://doi.org/10.1080 /13662716.2016.1146125.

Martin, P., Mayer, T., \& Mayneris, F. (2011). Public support to clusters. A firm level study of French "local productive systems". Regional Science and Urban Economics, 41, $108-123$. https://doi.org/10.1016/j. regsciurbeco.2010.09.001.

Michalek, J., Ciaian, P., \& D'Artis, K. (2016). Investment crowding out: firm-level evidence from Northern Germany. Regional Studies, 50(9), 1579-1594. https://doi.org/10.1080 /00343404.2015.1044957.

Moreno, R., Paci, R., \& Usai, S. (2005). Spatial spillovers and innovation activity in European regions. Environment and Planning A, 37, 1793-1812. https://doi.org/10.1068/a37341.

Mowery, D., \& Rosenberg, N. (1989). Technology and the pursuing of economic growth. Cambridge: Cambridge University Press ISBN: 0-521-38033-2. 
Mytelka, L. K. (1991). Strategic partnerships and the world economy. London: Pinter Publishers.

Netval. (2014). Ricerca, valorizzazione dei risultati e impatto, XIII Rapporto Netval sulla Valorizzazione della Ricerca Pubblica Italiana. Pisa: Edizioni ETS.

OECD. (2010). The OECD innovation strategy: getting a head start on tomorrow. Paris: OECD Publishing. https://doi. org/10.1787/9789264083479-en.

Radas, S., Anić, I.-D., Tafro, A., \& Wagner, V. (2015). The effects of public support schemes on small and medium enterprises. Technovation, 38, 15-30. https://doi.org/10.1016/j. technovation.2014.08.002.

Romero-Jordan, D., Delgado-Rodriguez, M. J., Alvarez-Ayuso, I., \& de Lucas-Santos, S. (2014). Assessment of the public tools used to promote R\&D investment in Spanish SMEs. Small Business Economics, 43(4), 959-976. https://doi. org/10.1007/s11187-014-9575-3.

Sáez, C. B., Marco, T. G., \& Arribas, E. H. (2002). Collaboration in R\&D with universities and research centres: an empirical study of Spanish firms. R\&D Management, 32(4), 321-341. https://doi.org/10.1111/1467-9310.00264.

Santoro, M., \& Chakrabarti, A. (1999). Building industryuniversity research centers: some strategic considerations.
International Journal of Management Reviews, 3(3), 225244. https://doi.org/10.1111/1468-2370.00014.

Scandura, A. (2016). University-industry collaboration and firms' R\&D effort. Research Policy, 45, 1907-1922. https://doi. org/10.1016/j.respol.2016.06.009.

Sonn, J., \& Storper, M. (2008). The increasing importance of geographical proximity in technological innovation: an analysis of US patent citations, 1975-1997. Environment and Planning A, 40, 1020-1039. https://doi.org/10.1068/a3930.

Stiglitz, J. (1988). Economics of the public sector. New York: W.W. Norton and Company ISBN: 978-0-393-92522-7.

Von Ehrlich, M., \& Seidel, T., (2015). The persistent effects of place-based policy: evidence from the West-German. CESifo Working Paper No. 5373.

Wolff, G. B., \& Reinthaler, V. (2008). The effectiveness of subsidies revisited: accounting for wage and employment effects in business R\&D. Research Policy, 37(8), 1403-1412. https://doi.org/10.1016/j.respol.2008.04.023.

Zuniga-Vicente, J. A., Alonso-Borrego, C., Forcadell, F.-J., \& Galan, J. I. (2014). Assessing the effect of public subsidies on firm R\&D investment: a survey. Journal of Economic Surveys, 28(1), 36-67. https://doi.org/10.1111/j.14676419.2012.00738.x. 